\title{
Design and functionality of a segmented heat-storage prototype utilizing stable supercooling of sodium acetate trihydrate in a solar heating system
}

\author{
EngImair, Gerald; Moser, Christoph; Furbo, Simon; Dannemand, Mark; Fan, Jianhua
}

Published in:

Applied Energy

Link to article, DOI:

10.1016/j.apenergy.2018.03.124

Publication date:

2018

Document Version

Peer reviewed version

Link back to DTU Orbit

Citation (APA):

Englmair, G., Moser, C., Furbo, S., Dannemand, M., \& Fan, J. (2018). Design and functionality of a segmented heat-storage prototype utilizing stable supercooling of sodium acetate trihydrate in a solar heating system. Applied Energy, 221, 522-534. https://doi.org/10.1016/j.apenergy.2018.03.124

\section{General rights}

Copyright and moral rights for the publications made accessible in the public portal are retained by the authors and/or other copyright owners and it is a condition of accessing publications that users recognise and abide by the legal requirements associated with these rights.

- Users may download and print one copy of any publication from the public portal for the purpose of private study or research.

- You may not further distribute the material or use it for any profit-making activity or commercial gain

- You may freely distribute the URL identifying the publication in the public portal 


\title{
Design and functionality of a segmented heat-storage prototype utilizing stable supercooling of sodium acetate trihydrate in a solar heating system
}

\author{
Gerald Englmair ${ }^{1, *}$, Christoph Moser $^{2}$, Simon Furbo ${ }^{1}$, Mark Dannemand ${ }^{1}$ and Jianhua Fan ${ }^{1}$ \\ ${ }^{1}$ Department of Civil Engineering, Technical University of Denmark, Brovej 118, 2800 Kgs. Lyngby, Denmark \\ ${ }^{2}$ Institute of Thermal Engineering, Graz University of Technology, Inffeldgasse 25/B, 8010 Graz, Austria
}

\section{Highlights}

- Combined short- and long-term heat-storage prototype for domestic solar heating

- Interplay of solar collectors, four $200 \mathrm{~kg}$ PCM units and a $735 \mathrm{~L}$ water tank

- Functionality of a segmented heat storage utilizing stable supercooling of SAT

- Solidification of supercooled SAT was started by a seed crystal injection device

- Supply temperatures and thermal power during PCM charge and discharge were evaluated

\begin{abstract}
A solar heating system with $22.4 \mathrm{~m}^{2}$ of solar collectors, a heat storage prototype consisting of four $200 \mathrm{~kg}$ phase-change material (PCM) storage units, and a $735 \mathrm{~L}$ water tank was designed to improve solar heat supply in single-family houses. The PCM storage utilized stable supercooling of sodium acetate trihydrate composites to conserve the latent heat of fusion for long-term heat storage. A control strategy directed heat from a solar collector array to either the PCM storage or a water buffer storage. Several PCM units had to be charged in parallel when the solar collector output peaked at $16 \mathrm{~kW}$. A single unit was charged with $27.4 \mathrm{kWh}$ of heat within four hours on a sunny day, and the PCM temperature increased from $20^{\circ} \mathrm{C}$ to $80^{\circ} \mathrm{C}$. The sensible heat from a single PCM unit was transferred to the water tank starting with about $32 \mathrm{~kW}$ of thermal power after it had fully melted at $80{ }^{\circ} \mathrm{C}$. A mechanical seed crystal injection device was used to initialize the crystallisation of the sodium acetate trihydrate after it had supercooled to room temperature. The unit discharge during solidification peaked at $8 \mathrm{~kW}$. Reliable supercooling was achieved in three of the four units. About $80 \%$ of latent heat of fusion was transferred from PCM units after solidification of supercooled sodium acetate trihydrate to the water tank within 5 hours. Functionality tests with practical operation conditions on the novel, modular heat-storage configuration showed its applicability for domestic hot water supply and space heating.
\end{abstract}

Keywords: Solar heating system; heat storage prototype; phase change material; sodium acetate trihydrate; stable supercooling. 


\section{Nomenclature}

\section{Dimensional variables}

$\mathrm{c}_{\mathrm{p}}$

G

$\mathrm{m}$

Q

Q

$\rho$

t

$\mathrm{T}$

$\dot{\mathrm{V}}$

\section{Greek letters}

$\Delta \mathrm{h}$

$\Delta \mathrm{H}$

$\Delta \mathrm{T}$

\section{Subscripts}

\section{AMB}

B

COLL

IN

L specific heat capacity $(\mathrm{kJ} / \mathrm{kg} \mathrm{K})$

global irradiance $\left(\mathrm{W} / \mathrm{m}^{2}\right)$

mass $(\mathrm{kg})$

thermal energy, heat $(\mathrm{kWh})$

thermal power, heat transfer rate $(\mathrm{kW})$

density $\left(\mathrm{kg} / \mathrm{m}^{3}\right)$

time (s)

temperature $\left({ }^{\circ} \mathrm{C}\right)$

volume flow rate $(1 / \mathrm{min})$

Abbreviations

ABS

$\mathrm{CMC}$

DHW

EDTA

HTF

HX

$\mathrm{P}$

PCM

SA

SAT

$\mathrm{SH}$

V losses

phase-change material

outlet line

surface

steel

total, on the collector plane

upper

water

acrylonitrile butadiene styrene

carboxymethyl cellulose

domestic hot water

ethylenediaminetetraacetic acid

heat transfer fluid

heat exchanger

pump

phase-change material

sodium acetate

sodium acetate trihydrate

space heating

2-way valve 


\section{Introduction}

With the increasing utilization of energy from renewable sources, solar heating has become one of the most promising technologies for reducing the percentage of fossil fuels in future energy systems. Thermal energy storage is a key system component for utilizing renewable energy sources to a greater extent [1]. Solar combisystems are designed to achieve high solar fractions of heat supply for domestic buildings. Their task is to collect energy from the sun and store it until it is used for domestic hot water or for space heating/cooling. The importance of heat storage with small heat loss and good interplay with solar collectors is well known [2], [3]. Andersen and Furbo [4] and Thür and Furbo [5] have conducted detailed investigations on the design and potential of solar combisystems and on efficient heat storage using hot water storage tanks.

Due to insufficient solar radiation during the winter and the high energy requirement for space heating at high latitudes, long-period and even seasonal heat storage technology for solar heating applications has attracted more and more attention in recent decades [6], [7].

\subsection{Novel thermal energy storage concepts}

Materials that might enable more efficient storage of heat over long periods, were investigated by Ristić et al. [8]. Promising heat storage concepts are based on solid sorption materials which utilize the adsorption of water vapour [9][11], the principle of absorption (e.g. with sodium-hydroxide and water [12] as demonstrated by Fumey et al. [13] and Daguenet-Frick et al. [14]), thermochemical reactions (as demonstrated by Zondag et al. [15]), and phase-change materials (PCMs). Salt hydrate reactions have been considered for their high potential energy storage density [16]. The thermophysical properties of several salt hydrates are appropriate for utilization as PCMs in building applications [17].

As reported by Quinnel and Davidson [18], the combined use of material properties, such as reaction enthalpy and sensible heat capacity, is potentially advantageous in new materials for domestic heat storage applications. The stable supercooling of PCMs allows the combined use of the latent heat of fusion and sensible heat capacity. This is one longterm heat storage concept that promises more efficient utilization of solar heat for low-energy buildings in summer and transitional seasons [19]. In addition to salt hydrates, microstructured polyol-polystyrene composites have also been considered for their stable supercooling properties [20].

Sodium Acetate Trihydrate (SAT) is a salt hydrate with a melting point of $58^{\circ} \mathrm{C}$ and a relatively high latent heat of fusion $(264 \mathrm{~kJ} / \mathrm{kg}$ ) [21]. It contains $60.3 \% \mathrm{wt}$ of sodium acetate and $39.7 \% \mathrm{wt}$ of water. If SAT has been fully melted and heated to a temperature higher than $\sim 77^{\circ} \mathrm{C}$ (as indicated in the binary phase diagram of sodium acetate and water [22]), it can cool down to ambient temperature in its liquid phase without releasing the heat of fusion; this is called "supercooling", "subcooling" or "undercooling". The latent heat is conserved until crystallisation occurs. When a PCM is in the supercooled state and in thermal equilibrium with its surroundings, it can in principle store heat indefinitely, so it could be used for seasonal heat storage [23]. Once crystallisation is activated, the latent heat of fusion is released, and the material temperature increases almost immediately to the melting temperature [24].

On the other hand, the cooling down of liquid material to temperatures substantially below its melting temperature is considered to hinder the conventional use of PCMs for thermal energy storage [25], [26]. Ways of reducing the supercooling of SAT have therefore been investigated [27], [28].

Various designs have been developed for domestic heat storage units using PCMs. The performance of heat 
exchangers with large PCM volumes in metal containers with an internal bundle of tubes has been studied by LopezNavarro et al. [29]. Shell-and-tube heat exchangers [30] and macro encapsulated PCM in water vessels [31] have been tested for sensible-latent heat storage. Moreno et al. [32] have investigated the corrosion of metal and metal alloy containers in contact with various PCMs. Arteconi et al. [33] argue that the application of PCMs in thermal energy storage systems can help manage the mismatch between the availability of renewable electricity and the demand for electricity, for example in buildings where hot water, heating and cooling are delivered by heat pumps and air conditioning.

\subsection{Sodium acetate trihydrate compositions}

SAT is available in large quantities in food-grade products (E262i), which makes it suitable for application in domestic buildings. To stabilize SAT for heat storage applications, adding water (resulting in a lower SA-water ratio) was first studied by Furbo in 1978 [34]. Later investigations on a heat storage unit containing about $200 \mathrm{~kg}$ of an SAwater composition with a water content greater than $40 \% \mathrm{wt}$ [35] showed a decrease in conserved latent heat of fusion when several cycles of heating and cooling were applied.

To overcome the problem of phase separation in the incongruently melting SAT, various additives can be added to form a more stable composition. One proposed solution is to add Carboxymethyl Cellulose (CMC) as a thickening agent [36]. The main drawback of thickening agents is that they reduce heat transfer by convection. Highly conductive graphite powder can improve the thermal conductivity of a composition with a thickening agent [37]. Paraffin oil, which does not mix with SAT, can be added to increase heat transfer by filling insulating cavities formed during the solidification and contraction of the PCM composition [38] due to density differences during phase change [37]. Another way of reducing the problem of phase separation is to increase the solubility of the crystal water in the melted and supercooled SAT mixture. The heat contents of SAT composites with various concentrations of thickening agents, the chelating agent Disodium Ethylenediaminetetraacetic Acid (EDTA), and polymer additives have been investigated by Kong et al. [39].

\subsection{State of the art}

Experiments with rectangular and cylindrical PCM containers with SA-water and CMC composites have been reported by Zhou and Xiang [40]. Their results show that more stable supercooling could be achieved with longer charging periods (to ensure the full melting of all SAT crystals), a relatively low cooling rate, and a lower inner surface roughness in PCM containers. The bending of rough metal surfaces might be an uncontrolled activation mechanism during cooling [41].

In previous work by the present authors, we tested various heat storage designs [42], each based on a flat box with SAT and additives as the heat storage material. A functioning design was identified as consisting of either steel or stainless steel units with room for PCM expansion in the box. Its thermal behaviour was then further investigated by using numerical models [38], [43]. The actual design and its characteristics with SAT as the heat storage material were investigated by Dannemand et al. under laboratory conditions [35]. It was proved and documented that the stable supercooling of SAT composites in flat boxes and cylindrical vessels [44] is enabled by: a) avoiding pressure changes in the PCM container (e.g. by using a membrane expansion vessel), b) smooth inner container surfaces, and c) heating 
up the whole material volume to a minimum temperature of $\sim 77^{\circ} \mathrm{C}$.

A numerical model for a solar combisystem for the Danish climate with an ideal seasonal PCM heat storage with SAT has been used to calculate the possible solar fraction of heat supply in a low-energy house [45], [36]. It was calculated that solar fractions in the range of $80-100 \%$ can only be achieved if the PCM storage volume is subdivided into segments. Individual control with respect to charging, discharging, and the initialization of solidification makes it possible to utilize a small storage volume to match domestic heat demand while conserving the remaining energy.

In this context, the controlled initialization of crystallization is a key requirement. Several methods have been investigated. Successful initiation of crystallization of supercooled SAT with ultrasonic waves has been reported by Seo et al. [46], but other researchers [47] say that the crystallization failed. Starting solidification by cooling supercooled SAT below its crystallization point (around $-15^{\circ} \mathrm{C}$ ) [48] has been successfully achieved using local evaporation of carbon dioxide on the outside of a container wall in steel [35]. Another way to cool down SAT locally is to use Peltier elements. A set-up with double-staged Peltier elements reached $-30{ }^{\circ} \mathrm{C}$ and would therefore be able to trigger the crystallization [49]. Adding seed crystals is another common method to initialize crystallization in laboratory set-ups [48], [50]. Crystallization with seed crystals works, if the seed crystals do not melt and become inactive [41]. Electric field nucleation has also been reported to work [24]. Activation methods based on local cooling as well as seed crystal injection seem to be reliable.

\subsection{Storage principles with SAT}

SAT composites in closed containers can be utilized for heat storage with or without stable supercooling. In the temperature range of $20-90{ }^{\circ} \mathrm{C}$, SAT has a specific heat capacity of $2.9 \mathrm{~kJ} /(\mathrm{kg} \mathrm{K})$ in liquid and supercooled state [22] and its density is $1280 \mathrm{~kg} / \mathrm{m}^{3}$ in liquid phase [51], [52]. This results in a specific, volumetric heat capacity of $3.71 \mathrm{~kJ} /(1$ $\mathrm{K})$ - a value close to that of water $(4.18 \mathrm{~kJ} /(1 \mathrm{~K})$ [53]). The thermal conductivity of liquid SAT $(0.4 \mathrm{~W} /(\mathrm{m} \mathrm{K})$ [22]) is lower than for water $(0.64 \mathrm{~W} /(\mathrm{m} \mathrm{K})$ [54]). These material properties make SAT also suitable for sensible heat storage applications.

Operation states are defined by the specific energy content and temperature of SAT at atmospheric pressure. Fig. 1 shows the three different storage principles $(\mathrm{a}-\mathrm{c})$ which can be combined for the short-term and long-term storage of heat:

(a) Its high heat-storage capacity at melting point is utilized (as latent heat storage) when no passivation of nucleation seeds is achieved during the charging of SAT composites.

(b) Most of the heat of fusion can be transferred to a lower temperature level, reducing heat losses to the environment. When SAT composites supercool at ambient temperature, no heat loss due to heat transfer to the environment occurs until crystallization is initialized. Only changes within the material composition, such as phase separation, can reduce the potential of conserved heat.

(c) When SAT composites remain in liquid state below their melting point, it is possible to utilize sensible heat storage without phase change.

Storage principles (a) and (c) are relevant for short heat-storage periods (hours, days), while the utilization of stable supercooling (b) is beneficial for long-term storage (weeks, months). 


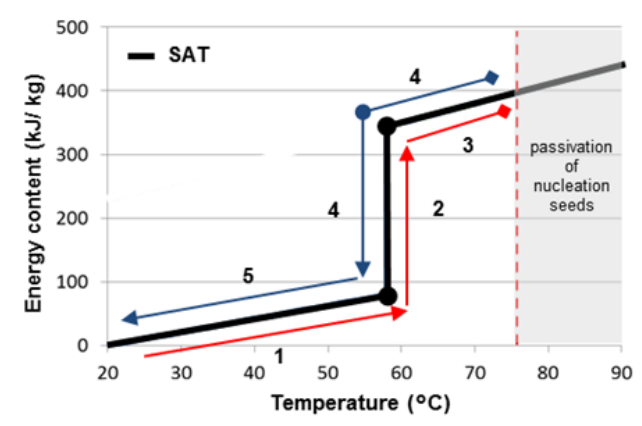

a) Heat of fusion and sensible heat capacity without supercooling

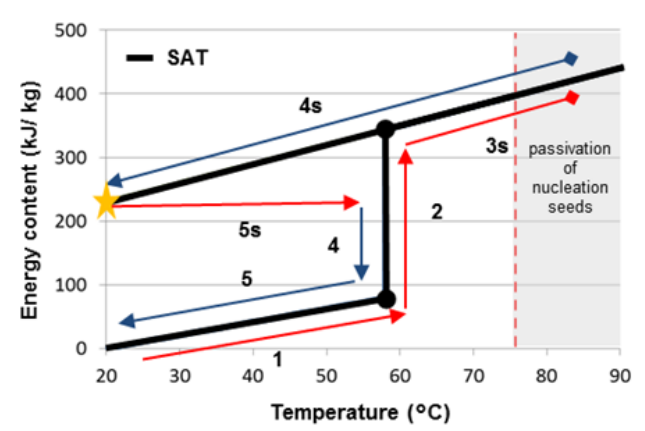

b) Heat of fusion and sensible heat capacity with stable supercooling
Heat storage operation states:

1 Charge of solid material

$2 \quad$ Melting

3 Charge of liquid material, nucleation seeds remain

3s Charge of liquid material, passivated seeds

4 Discharge from liquid state with solidification

4s Discharge of liquid material without solidification

5 Discharge of solid material

5s Initialization of crystallization

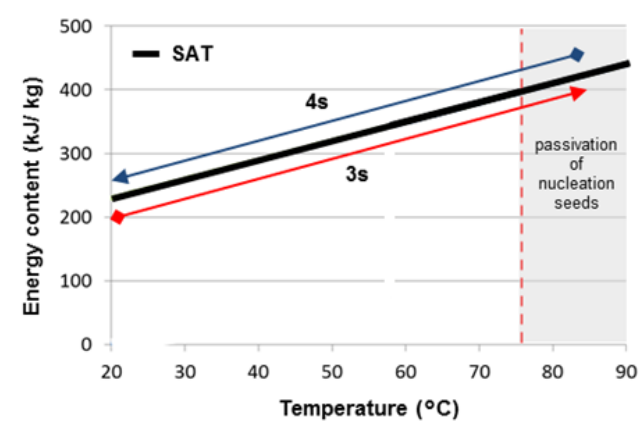

c) Sensible heat capacity of supercooled, liquid phase

Fig. 1. Heat storage operation states with SAT composites.

\subsection{Scope}

This article introduces a heat storage system consisting of four heat storage units with PCM comprising a segmented PCM heat storage. The segmented heat storage was connected to a water buffer storage tank and solar collectors in a solar combisystem demonstrator. The combisystem was subject to energy draw-offs representing realistic domestic hot water (DHW) and space heating (SH) demands. An operation strategy for the PCM-solar combisystem was developed (based on numerical studies [36] and design criteria for solar combisystems) and applied to the system. We studied the thermal behaviour of the segmented PCM heat storage while charging with the solar collector and discharging to the water buffer storage. We investigated the ability of PCM units to supercool after being charged with solar heat as the heat source and to operate as long-term and short-term heat storage. We designed a mechanical activation device for the initialization of crystallization, which allowed the injection of seed crystals into the supercooled SAT in closed containers to initialize crystallization when desired.

Investigations on a solar heating system with four heat storage units, each with $200 \mathrm{~kg}$ of SAT, and using phase change and stable supercooling for long-term heat storage have not previously been reported in the literature.

Various heat storage operation states (Fig. 1) occurred in the PCM storage during the operation period from August to November 2015. Typical operation modes were analysed and evaluated in relation to the functionality of the heat storage prototype. Temperature developments in the heat transfer fluid (HTF) during the charging and discharging of PCM units in the context of the resulting heat transfer rates were the basic criteria for evaluation. Previous laboratory tests on PCM units [35] have showed that heat transfer rates during charging are rather high in comparison to those during discharging. The discharge behaviour of PCM units is clearly a limiting factor for their functionality and therefore of special interest. 


\section{Heat storage design}

\subsection{PCM unit}

The flat units (length: $2.4 \mathrm{~m}$; width: $1.2 \mathrm{~m}$ ) with a height of $5 \mathrm{~cm}$ inside the enclosed PCM container (volume: 150 L) were constructed by the Danish company Nilan A/S [35]. A schematic diagram of a unit is shown in Fig. 2a. Parallel channel heat exchangers were attached on the top and the bottom of each flat PCM container. We used water as the HTF, and the volume of the heat exchangers was $32 \mathrm{~L}$ per unit. Thermocouples (TT-type) for the channel surface temperature measurements $\left(\mathrm{T}_{\mathrm{S} 1}, \mathrm{~T}_{\mathrm{S} 2}\right.$ and $\left.\mathrm{T}_{\mathrm{S} 3}\right)$ were installed centralized at a distance of $0.5 \mathrm{~m}$ from the front end of the heat exchangers. An air expansion chamber was connected to the expansion vessel to minimize any pressure change during material expansion (about 10\% [37]) from solid to liquid state.
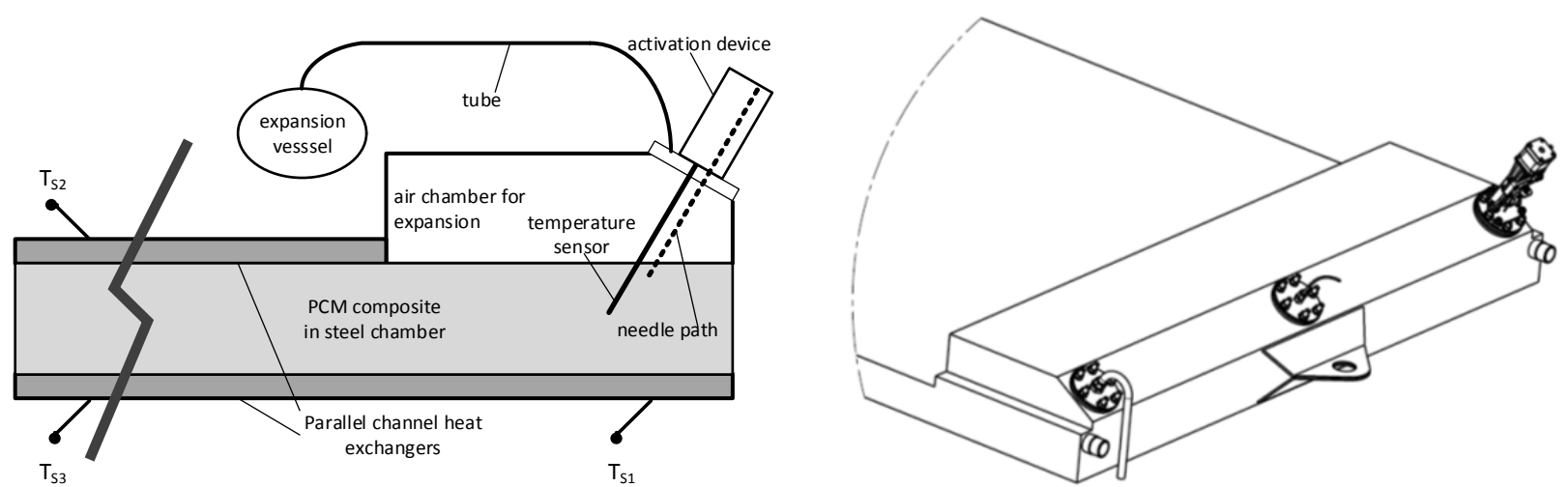

Fig. 2. a) Diagram of PCM unit design (cross-section); b) Perspective drawing of a PCM unit (view with air chamber for expansion).

The activation device was mounted on a flange of the air expansion chamber of each PCM unit (Fig. 2b). Using this device, solid SAT crystals were added to the supercooled SAT composite. A thermocouple inside a hollow metal cylinder (diameter: $3 \mathrm{~mm}$ ) was mounted on the central flange of the air expansion chamber to allow temperature measurement in the middle of the PCM. The remaining flange was used to connect the air expansion chamber of the unit to a membrane expansion vessel (50 L). Fig. 2 b also shows the inlet connections (tubes with a diameter of 3/4") of the two heat exchangers.

\subsection{Segmented PCM heat storage}

Four flat units were stacked to form the PCM heat storage. Two of the units (units 2 and 4) were made of stainless steel, while the other two were made of steel (units 1 and 3). A two-metre-high assembly (Fig. 3a) with sufficient space for maintenance between the units was built. To make it possible to investigate their performance separately, each PCM unit was insulated with $10 \mathrm{~cm}$ of foam and separately connected to the hydraulic circuit (Fig. 3b). Water was used as the HTF. Motor valves $\left(V_{1}, V_{2}, V_{3}\right.$, or $\left.V_{4}\right)$ were mounted at the inlet for each unit to control the flow through each heat exchanger. This allowed individual charging and discharging for each PCM unit, when both the upper and the lower heat exchanger transferred heat to and from the unit. 

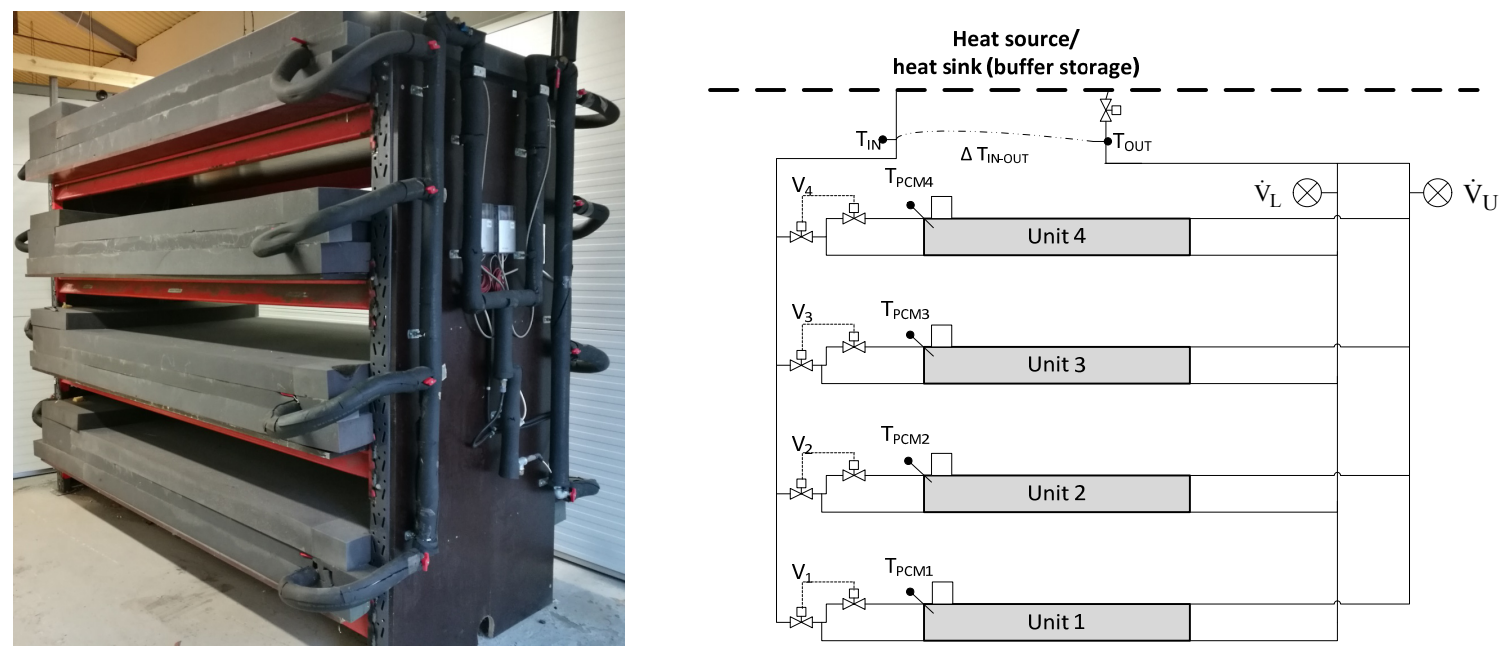

Fig. 3. a) Photograph of the segmented PCM storage; b) Diagram of the hydraulic integration of the PCM units.

The hydraulic layout (Fig. 3b) allowed separate measurement of the flow rates of the lower heat exchangers $\left(\dot{V}_{\mathrm{L}}\right)$ and the upper heat exchangers $\left(\dot{\mathrm{V}}_{\mathrm{U}}\right)$, resulting in an accumulated flow rate $\left(\dot{\mathrm{V}}_{2}\right.$ in Fig. 5). Two motor-valves per unit prevented unwanted backflows and thermally driven circulation. Control of charging and discharging of the heat storage units was based on the temperatures $\left(\mathrm{T}_{\mathrm{PCM} 1}, \mathrm{~T}_{\mathrm{PCM} 2}, \mathrm{~T}_{\mathrm{PCM} 3}\right.$ or $\left.\mathrm{T}_{\mathrm{PCM} 4}\right)$ of the PCM layers. The HTF temperatures at the inlet $\left(\mathrm{T}_{\mathrm{IN}}\right)$ to the units and at the outlet ( $\left.\mathrm{T}_{\mathrm{OUT}}\right)$ from the units were measured with thermocouples. A thermopile was used to measure the temperature difference between $\mathrm{T}_{\mathrm{IN}}$ and $\mathrm{T}_{\text {OUT }}$.

Each PCM unit was filled with a different SAT composite (Table 1), with the aim of investigating their stability in the system demonstration. Previous investigations [39] have shown the highest heat contents $(\Delta \mathrm{h})$ when $1 \% \mathrm{wt}$ of CMC (as in units 1 and 2) and 1\%wt (unit 3) or 2\%wt (unit 4) of EDTA were added to SAT. Unit 3 needed 1\%wt extra water to achieve a fully dissolved solution during melting. Moreover, highly conductive graphite powder and paraffin oil were added in unit 1 to study their impact on heat transfer.

The PCM container of unit 4 was damaged and refilled before the installation. During refill no exact weight measurement was carried out.

Table 1. PCM compositions in units.

\begin{tabular}{lllll}
\hline & Unit 1 & Unit 2 & Unit 3 & Unit 4 \\
\hline PCM composition & SAT + 1\% CMC & SAT + 1\% CMC & SAT + 1\% water & SAT + 2\% EDTA \\
& $+2 \%$ graphite + 5 L oil & & $+1 \%$ EDTA & \\
PCM mass & $202 \mathrm{~kg}$ & $220 \mathrm{~kg}$ & $202 \mathrm{~kg}$ & unknown \\
$\Delta \mathrm{h} \mathrm{[39]}$ & $211 \mathrm{~kJ} / \mathrm{kg} *$ & $211 \mathrm{~kJ} / \mathrm{kg}$ & $216 \mathrm{~kJ} / \mathrm{kg} * *$ & $215 \mathrm{~kJ} / \mathrm{kg}$ \\
$\Delta \mathrm{H}$ unit & $40759 \mathrm{~kJ}$ & $46420 \mathrm{~kJ}$ & $42004 \mathrm{~kJ}$ & - \\
\hline
\end{tabular}

${ }^{*}$ Value for SAT with $1 \%$ CMC, added graphite and oil was assumed to be additional non-reactive mass

${ }^{* *}$ Value for SAT with 1\% EDTA without extra water in the composition 


\subsection{Activation device}

A mechanism for the initialization of PCM crystallization was realised as a prototype with components in acrylonitrile butadiene styrene (ABS) using a fused filament fabrication method with a 3D-printer. ABS has a relatively high temperature resistance compared to other 3D-printing materials. The activation device consisted of two main parts (Fig. 4a): the sealing unit and the triggering unit.

The sealing unit secured the tightness of the PCM container and allowed the solid SAT crystals to be inserted via a hollow needle into the supercooled SAT. The unit had two different types of sealing membrane. The lower membrane had a low resistance against puncture with a hollow needle and was coated on the bottom with Teflon, which was in direct contact with the expansion chamber. The upper membrane was made of natural rubber, which can resist puncture for longer periods.
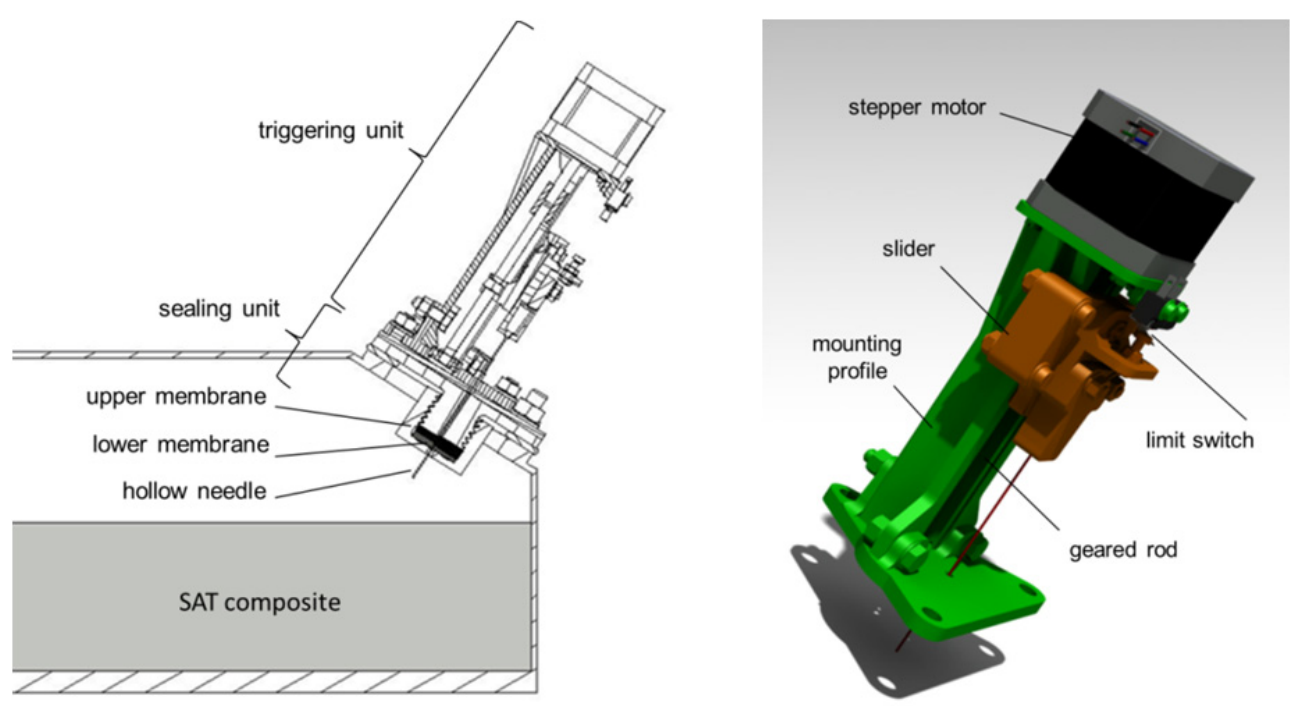

Fig. 4. a) Diagram of the triggering unit (in moving position) mounted on the sealing unit;

b) Drawing of the assembled triggering unit.

The triggering unit (Fig. 4) was designed to be detached or mounted without affecting the PCM. The three main parts of the triggering unit were the mounting profile, a slider, and a stepper motor with a geared rod. The mounting profile provided the mounting holes for the stepper, the limit switch, and the fixture to the sealing unit. The slider moved on the sliding surface of the mounting profile. Upward and the downward forces were transferred by means of a nut, which was driven by the geared rod. A hollow needle and an adjusting screw for the limit switch were fixed at the top of the slider.

The hollow needle contained the SAT crystals, and its initial position was outside the PCM box. The membranes ensured that no crystal seeds fell into the PCM before crystallization was triggered. To activate the PCM unit, the needle was injected through the membranes. Control was realised by a microcontroller board (ATMega 2560), a stepper driver (A4988), and an RS323 interface. The following control logic was programmed in the microcontroller: The slider moved upwards, until the limit switch was hit. The slider then moved downward a predefined distance and pushed the hollow needle through the membranes and into the liquid SAT. After a predefined waiting time the slider moved upward again until the limit switch was hit again. 


\subsection{Heat storage configuration}

To apply the concept of a segmented PCM heat storage with water buffer storage to a heat source with fluctuating power, we built a storage configuration for controlled heat transfer. Hydraulic pipework was realised from the heat source to both the PCM units and the water tank. The various hydraulic circuits were set by means of 2-way valves, so that heat could also be transferred from the PCM units to the water tank.

The components of the heat storage prototype configuration, including a solar collector circuit, are shown in Fig. 5. In principle, any heat source utilizing solar energy (such as a solar collector array or an electrical heater supplied by a photovoltaic system) can be integrated via a heat exchanger (HX). To overcome the problem of limited heat transfer to the PCM units [35] and to utilize solar energy for heat supply in periods of sunshine directly, domestic hot water (DHW) and space heating (SH) are supplied via the water tank. The water storage (735 L) was designed as tank-in-tank buffer storage with good thermal stratification behaviour for efficient short-term heat storage. The inner tank (175 L), situated in the centre of the tank) contained domestic water, which entered at the bottom during DHW tapping from the top of the tank. The outer tank volume contained water used as the HTF in a closed hydraulic system with a membrane expansion vessel for compensation for pressure changes. The static HTF pressure was maintained below 1 bar to secure the PCM units. DHW was heated up via the mantle surface of the inner tank from the warmer HTF in the outer tank volume. A space heating circuit ( $\mathrm{SH}$ ) was connected to the outer tank with an inlet at the bottom and draw-off in the middle of the tank. Pipes (3/4", carbon steel), fittings and the plate heat exchanger (HX) were insulated with $19 \mathrm{~mm}$ of elastomeric foam.

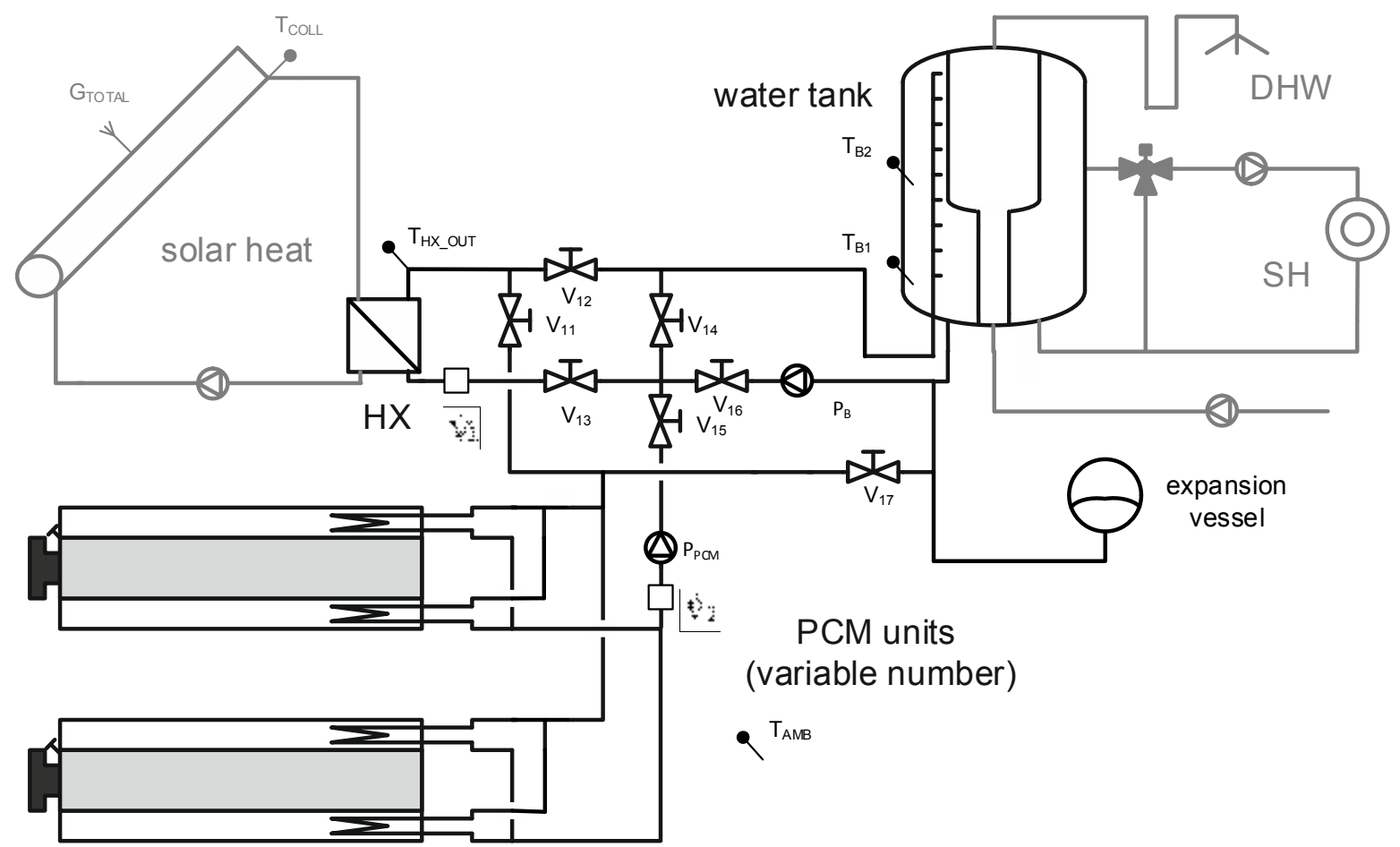

Fig. 5. Diagram of the configuration of the heat storage prototype (heat storage components in black, integrated heat source and heat sink components in grey). 
To charge the buffer storage, water from the bottom of the outer tank was circulated, heated up via the HX, and entered the tank via a prototype polymeric inlet stratifier of the same kind as investigated by Dragsted et al. [55]. Three valves $\left(\mathrm{V}_{12}, \mathrm{~V}_{13}\right.$ and $\left.\mathrm{V}_{16}\right)$ were open during direct charging from a solar heat source and circulation was driven by the buffer storage pump $\left(\mathrm{P}_{\mathrm{B}}\right)$.

To charge the PCM units, the pump $\mathrm{P}_{\mathrm{PCM}}$ was used to circulate water via $\mathrm{V}_{15}, \mathrm{~V}_{13}$, the $\mathrm{HX}$ and $\mathrm{V}_{11}$ to the segmented PCM heat storage. Heat transfer from the PCM heat storage to the water tank was realized via $V_{15}, V_{14}$ and $V_{17}$ when $\mathrm{P}_{\mathrm{PCM}}$ was switched on. This configuration (Fig. 5) enables the integration of any number of PCM units. Four PCM units were installed for the heat storage prototype presented here.

\section{Experimental investigations and calculations}

\subsection{Charging with solar heat}

A solar collector array (Fig. 6a), consisting of evacuated tubular collectors (type Kingspan Thermomax HP-450, total aperture area of $22.4 \mathrm{~m}^{2}$ ), was connected to the HX. It was set up with an inclination angle of $45^{\circ}$ and an azimuth angle of $12^{\circ}$ towards the east at the solar heating test facility of the Technical University of Denmark (northern latitude of $\left.55.8^{\circ}\right)$. The collectors had an optical efficiency of 0.75 , and their heat loss coefficients were $1.18 \mathrm{~W} /\left(\mathrm{m}^{2} \mathrm{~K}\right)$ and 0.01 $\mathrm{W} /\left(\mathrm{m}^{2} \mathrm{~K}^{2}\right)$. The solar irradiance on the tilted collector plane $\left(\mathrm{G}_{\text {TOTAL }}\right)$ was measured with a pyranometer, as indicated in Fig. 5.

Operation was realised with a LabView program controlling valves and pumps (as described in section 2.4) with a five-minute reaction time for changes. The sequence of tests was based on sensor readings (Fig. 5): The collector circuit pump was started when the outlet temperature $\left(\mathrm{T}_{\mathrm{COLL}}\right)$ of the collector was $10 \mathrm{~K}$ higher than the temperature at the bottom of the water storage $\left(\mathrm{T}_{\mathrm{B} 1}\right)$. The water tank (Fig. 6b) was charged until a temperature of $60{ }^{\circ} \mathrm{C}$ was reached in the middle of the water tank $\left(\mathrm{T}_{\mathrm{B} 2}\right)$. Charging of the buffer storage stopped when either the lower or the upper threshold value was met. When the upper threshold for the buffer storage was reached, the collector circuit flow stopped until a collector outlet temperature of $70{ }^{\circ} \mathrm{C}$ and sufficient solar irradiance $\left(\mathrm{G}_{\text {TOTAL }}>150 \mathrm{~W} / \mathrm{m}^{2}\right)$ was measured, and then the PCM heat storage was charged.

a)

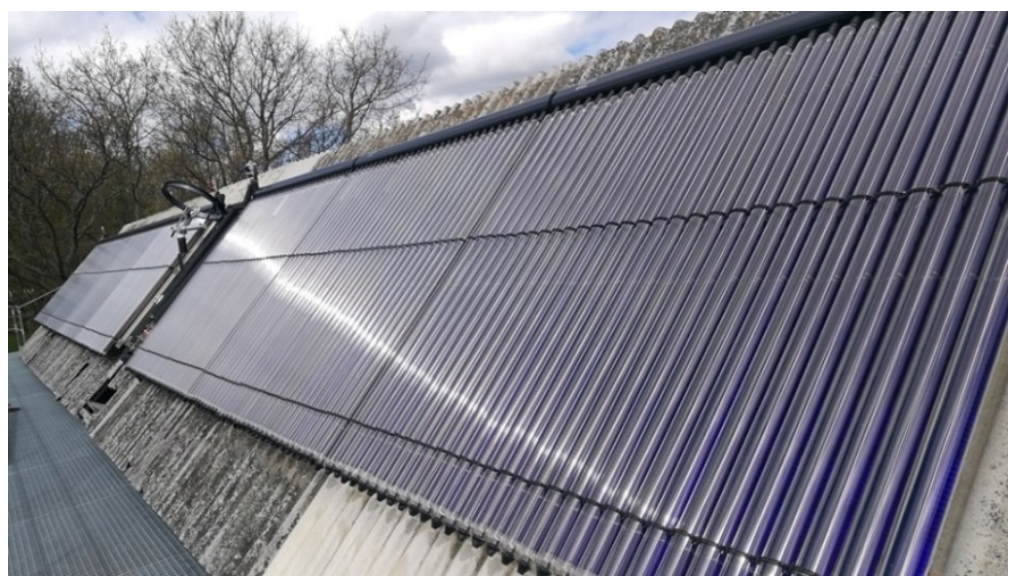

b)

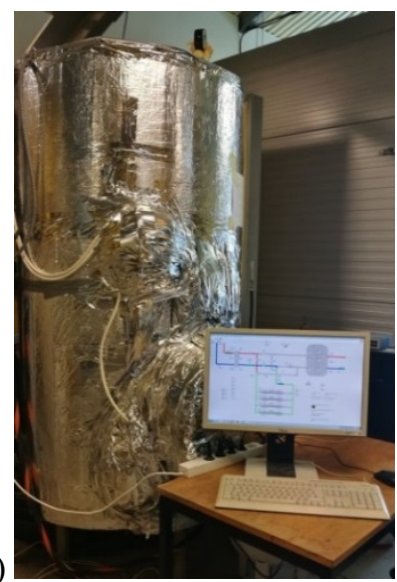

Fig. 6. a) Solar collector array; b) Water tank and graphical LabView interface for live data reading. 
The volume flow rate of the HTF in the collector circuit (type: TYFOCOR LS; consisting of propylene-glycol, water and inhibitors) was $5.5 \mathrm{~L} / \mathrm{min}$ during charging of the buffer storage and $21 \mathrm{~L} / \mathrm{min}$ during charging of the PCM storage units. On the secondary side of the heat exchanger, connecting the solar collector circuit with the heat stores, a HTF volume flow rate of $16.5 \mathrm{~L} / \mathrm{min}$ was used in the PCM charging circuit to ensure good heat transfer at the heat exchangers of the PCM units. A flow rate of $5.5 \mathrm{~L} / \mathrm{min}$ was chosen for charging the water buffer storage to allow buildup of thermal stratification.

Individual PCM unit charging was completed when the temperatures inside the PCM $\left(\mathrm{T}_{\mathrm{PCM}}\right)$ reached $80{ }^{\circ} \mathrm{C}$. Because of the fluctuating thermal power from the large solar collector array and the limited heat exchange capacity of PCM units, it was necessary to vary the number of PCM units being charged at the same time to prevent overheating of the HTF. The number of active PCM units was controlled by actuating the motor valves $V_{1}-V_{4}$ (Fig. 3b) based on the outlet temperature of the heat exchanger $\mathrm{T}_{\mathrm{HX} \_ \text {OUT }}$. When this reached $95{ }^{\circ} \mathrm{C}$, the next warmest unit (based on $\mathrm{T}_{\mathrm{PCM} 1^{-}}$ $\mathrm{T}_{\mathrm{PCM} 4}$ readings) was opened to the circuit, and both units were charged in parallel. When $\mathrm{T}_{\mathrm{HX} \_ \text {out }}$ dropped below $85^{\circ} \mathrm{C}$, the valve to the circuit for the coldest unit being charged was closed. PCM storage charging for the last unit stopped when $\mathrm{T}_{\mathrm{COLL}}<85^{\circ} \mathrm{C}$ and $\mathrm{G}_{\mathrm{TOTAL}}<150 \mathrm{~W} / \mathrm{m}^{2}$ or when $\mathrm{T}_{\mathrm{B} 2}$ fell below $50{ }^{\circ} \mathrm{C}$ so that buffer storage charging was activated.

\subsection{Discharging of liquid PCM without solidification}

Supercooling of PCM units was tested in parallel by passive cooling to the ambient and individually by active discharging via the water tank. During passive cooling, the heat loss rates ( $\left.\dot{Q}_{\text {Loss }}\right)$ were calculated based on the PCM temperature measured $\left(\mathrm{T}_{\mathrm{PCMi}}\right)$. The changes in the heat content of the steel container $\left(\mathrm{m}_{\mathrm{ST}}\right)$, of the water in the heat exchangers $\left(\mathrm{m}_{\mathrm{W}}\right)$, and of the material composite $\left(\mathrm{m}_{\mathrm{PCM}}\right)$ were calculated separately by their temperature-dependent specific heat capacities $\left(c_{p}\right)$. The specific heat capacity of a PCM is highly dependent on the water content of the composite. Calculations were therefore carried out as Araki et al. [9] proposed:

$$
\dot{\mathrm{Q}}_{\text {loss }}(\mathrm{t})=\left(\mathrm{m}_{\mathrm{ST}} \cdot \mathrm{c}_{\mathrm{P}_{\mathrm{ST}}}+\mathrm{m}_{\mathrm{W}} \cdot \mathrm{c}_{\mathrm{p}_{\mathrm{W}}}+\mathrm{m}_{\mathrm{PCM}} \cdot \mathrm{c}_{\mathrm{p}_{\mathrm{PCM}}}\right) \cdot\left(\frac{\mathrm{dT}_{\mathrm{PCMi}}}{\mathrm{dt}}\right)
$$

Heat loss coefficients for the PCM units were calculated by dividing the heat loss rate for a specific time step by the temperature difference between the PCM temperature and the ambient temperature $\left(\mathrm{T}_{\mathrm{AMB}}\right) \cdot \mathrm{T}_{\mathrm{AMB}}$ was measured $2 \mathrm{~m}$ from the PCM heat storage at the height of unit 2 (as indicated in Fig. 5). Mean values of the heat loss coefficients were calculated from data of two independent cooling periods (5 days each) in August and October 2015. Starting from a temperature of approximately $80{ }^{\circ} \mathrm{C}$, the $\mathrm{PCM}$ was cooled down to a temperature of around $30{ }^{\circ} \mathrm{C}$ and remained in the liquid phase.

Active discharging of PCM was applied after a rest period (no heat transfer via the hydraulic circuit) of at least two hours after full charge was accomplished. Constant temperatures around $25^{\circ} \mathrm{C}$ at the inlet $\left(\mathrm{T}_{\mathrm{IN}}\right)$ to the segmented PCM volume were realised by cooling the water tank via the SH circuit connections. In this way, equal discharge conditions were realised. Volume flow rates of $5 \mathrm{~L} / \mathrm{min}$ and $10 \mathrm{~L} / \mathrm{min}$ were applied by manual control of $\mathrm{P}_{\mathrm{PCM}}$ until the PCM layer temperatures fell below $60^{\circ} \mathrm{C}$. 


\subsection{Initialization of crystallization and discharge from liquid state with solidification}

After full charge $\left(\mathrm{T}_{\mathrm{PCMi}}>80^{\circ} \mathrm{C}\right)$ was achieved, the PCM units rested for six days before solidification took place. The PCM supercooled down to ambient temperature $\left(25^{\circ} \mathrm{C}\right)$. The crystallization and release of the latent heat of fusion from the supercooled SAT was initialized (activated) when seed crystals were added to the solution. PCM activation was first tested by manual injection of a hollow needle containing SAT crystals via the mounted sealing unit into the PCM chamber (Fig. 4a). Later, mounted triggering units (Fig. 4b) were applied with the previously described activation sequence. Each triggering device was tested individually.

In the first test sequence, heat was discharged to the initially cold buffer storage tank. HTF circulation was started before PCM crystallisation was activated. The HTF volume flow rate was set to $2.13 \mathrm{~L} / \mathrm{min}$ by manual control of $\mathrm{P}_{\mathrm{B}}$. During crystallization, the PCM temperature increased to approximately $58^{\circ} \mathrm{C}$ and the discharge was stopped when the PCM temperature fell back to $50^{\circ} \mathrm{C}$.

In a later test with a volume flow rate of $5 \mathrm{~L} / \mathrm{min}$, the discharge was interrupted by automated buffer storage charging from the solar collector array. The water tank was cooled via SH connections during the test.

\subsection{Data processing}

Thermocouples and thermopiles were connected to a National Instruments 16-channel thermocouple CompactDAQ module (NI9214). Flow meter signals were read via a 32-channel digital input/output CompactDAQ module (NI9403). Data was logged at 10-second intervals. Heat transfer analysis was based on averaged values for 1-minute and 1-hour data. Uncertainties in evaluated measurements resulted mainly from the sensors installed (Table 2).

Table 2. Installed measurement devices.

\begin{tabular}{l|c|c}
\hline \multicolumn{1}{c|}{ Device } & Type & Uncertainty \\
\hline Thermocouple $\left(\mathrm{T}_{\mathrm{Bi}}, \mathrm{T}_{\mathrm{COLL}}, \mathrm{T}_{\mathrm{HX} \_ \text {OUT }}, \mathrm{T}_{\mathrm{PCMi}}, \mathrm{T}_{\mathrm{Si}}\right)$ & TT-type (copper/ constantan) & $0.5 \mathrm{~K}[56]$ \\
Thermopile $\left(\Delta \mathrm{T}_{\mathrm{IN}-\mathrm{OUT}}\right)$ & $\begin{array}{c}\text { 5-junction thermopile with TT-type } \\
\text { thermocouples }\end{array}$ & $0.1 \mathrm{~K}[56]$ \\
Flow meters $\left(\dot{\mathrm{V}}_{1}, \dot{\mathrm{V}}_{\mathrm{L}}, \dot{\mathrm{V}}_{\mathrm{U}}\right)$ & Brunata HGQ-1-R3 (class 2) & $\begin{array}{c}2 \% \text { of reading } \\
\text { (according to EN 1434)* } \\
15 \mathrm{~W} / \mathrm{m}^{2}\end{array}$ \\
Pyranometer $\left(\mathrm{G}_{\mathrm{TOTAL}}\right)$ & Kipp \& Zonen CM3 & $\begin{array}{c}\text { (below 200 W/m } \mathrm{m}^{2} \text { ) } \\
\text { [manufacturer information] }\end{array}$ \\
\hline
\end{tabular}

"The accuracy range was experimentally proved for the applied flow rate range before installation.

Heat transfer rates in the PCM circuit were calculated in the following way (negative temperature difference during discharge):

$$
\dot{\mathrm{Q}}=\dot{\mathrm{V}}_{\mathrm{i}} \cdot \mathrm{cp}_{\mathrm{p}} \cdot \rho \cdot \Delta \mathrm{T}_{\mathrm{IN}-\mathrm{OUT}}
$$

where $\dot{\mathrm{V}}_{\mathrm{i}}$ is the measured volume flow rate of the HTF, $\mathrm{c}_{\mathrm{p}}$ is the specific heat capacity of the HTF at mean temperature between $T_{\text {IN }}$ and $T_{\text {OUT }}$, and $\rho$ is the density of the heat transfer fluid at $T_{\text {OUT }}$, where the volume flow rates were measured. 


\section{Experimental results and discussion}

\subsection{Charging with solar heat}

During controlled heat storage operation, PCM charging took place after buffer storage charging. This sequence was beneficial because the collector circuit was pre-heated for the charging of PCM units, which require higher HTF flow temperatures. Fig. 7 shows heat transfer rates (hourly averaged values) to the PCM units (red curves) for a representative period. On two sunny days $\left(2^{\text {nd }}\right.$ and $3^{\text {rd }}$ of October), all modules were charged by solar heat (units 1,2 and 3 already being in supercooled state, and unit 4 from a partially melted state). The development of PCM temperatures in Fig. 7 shows that PCM charging was successfully applied with up to four units ( ${ }^{\text {rd }}$ of October) in parallel.

After full charging (a minimum temperature of $80{ }^{\circ} \mathrm{C}$ was achieved in all units) the units were passively cooled down. Three units went into supercooled state, while unit 4 solidified in the morning of the $5^{\text {th }}$ of October after supercooling $5 \mathrm{~K}$. The control system detected this PCM unit as the warmest and it was therefore charged again when solar heat was available during the afternoon of the same day.

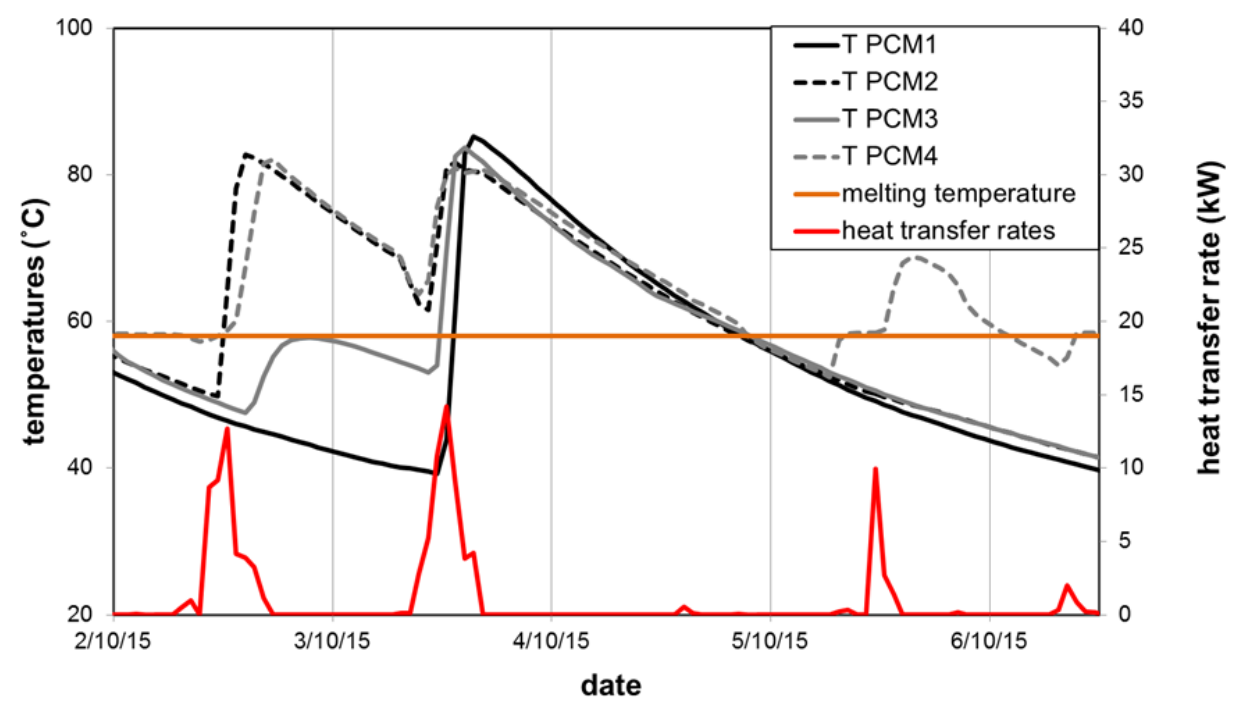

Fig. 7. PCM temperature developments in October 2015.

This test proved that parallel PCM unit charging is necessary on sunny days. With rising PCM temperatures, the heat transfer rates of the units fell. With parallel PCM unit charging, all the heat from the collectors could be transferred to the PCM units and boiling of the HTF was avoided.

PCM unit 4 never achieved stable supercooling during the test period. The SAT composite in this unit was similar to that in unit 3, which successfully supercooled. Even though unit 4 was frequently heated up to a PCM temperature of above $80{ }^{\circ} \mathrm{C}$, no stable supercooling was achieved. We think the supercooling failed because the PCM container was damaged. The failure meant we could not analyse the performance of the composite containing $2 \%$ wt EDTA. Our evaluations therefore focused on PCM units 1, 2 and 3.

During the test period, most single PCM unit charging was from an initially solid state. For example, PCM unit no. 1 was charged from ambient temperature $\left(21^{\circ} \mathrm{C}\right)$ in solid state during the afternoon of the $8^{\text {th }}$ of September 2015. Fig. 8 
shows the changes in the HTF inlet temperature $\left(\mathrm{T}_{\mathrm{IN}}\right.$, grey curve) and the HTF outlet temperature ( $\mathrm{T}_{\text {OUT }}$, black curve). As a consequence of the limited heat exchange capacity rate of the unit, the temperature of the charging circuit increased continuously for the first 150 minutes. Then the solar irradiance declined and $\mathrm{T}_{\mathrm{IN}}$ therefore decreased slightly. Charging of one PCM unit on a sunny afternoon with decreasing solar irradiance matches well with falling heat transfer rates (black dotted curve) during single unit charging when the PCM temperature (orange curve) was increasing.

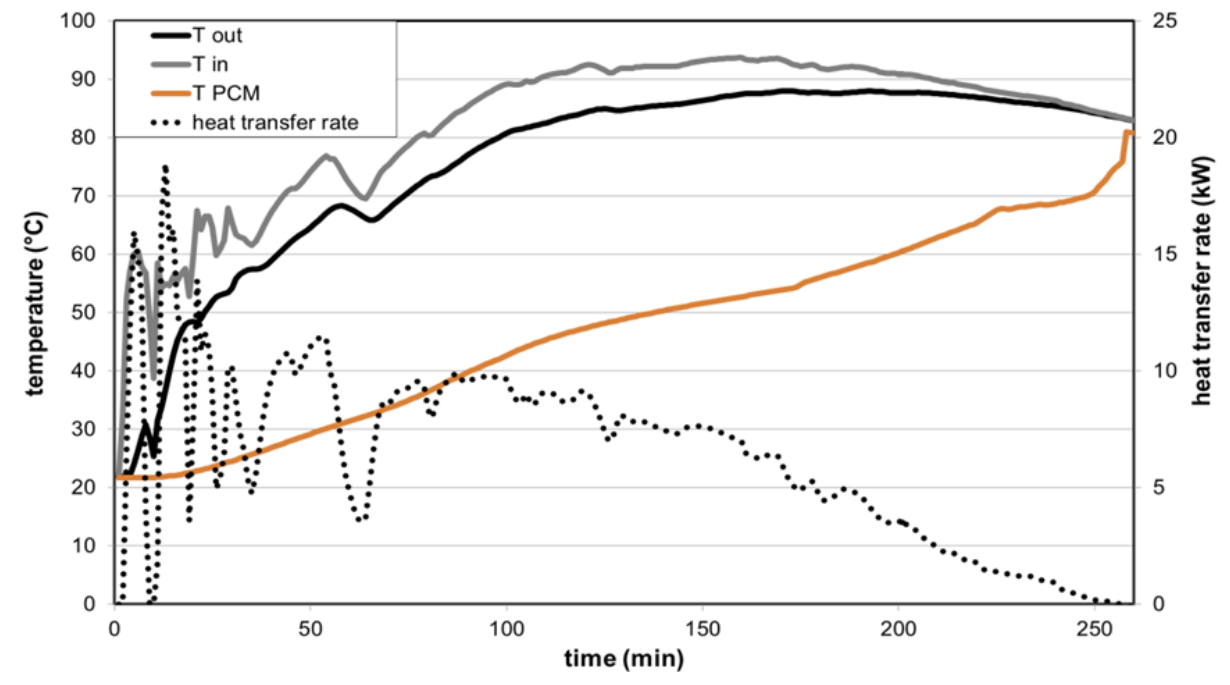

Fig. 8. Temperature and heat transfer rate developments during charging of unit1 from solid state.

Heat was transferred for 250 minutes. Charging (indicated by the heat transfer rate) stopped when $\mathrm{T}_{\mathrm{PCM}}$ reached 80 ${ }^{\circ} \mathrm{C}$. During this charging run, $27.4 \mathrm{kWh}$ heat was transferred. The solar irradiance fluctuated due to clouds. The heat transfer rate varied correspondingly. Heat transfer rates of up to $16 \mathrm{~kW}$ occurred at the beginning of the test. Later they decreased constantly as $\mathrm{G}_{\mathrm{TOTAL}}$ decreased.

A sharp increase in the $\mathrm{T}_{\mathrm{PCM}}$ can be seen after 240 minutes of charge. This indicates that the PCM was fully melted and convection of the liquid phase was taking place at the temperature sensor. Because $\mathrm{T}_{\mathrm{PCM}}$ is measured in a single location, its reading does not represent the mean material bulk temperature during dynamic charging or discharging.

\subsection{Passive discharge of PCM units}

Significant heat losses occurred during parallel PCM unit cooling after full charge. Ambient air temperature differences between day and night of up to $7 \mathrm{~K}$ were measured. The calculation of heat loss coefficients (Table 3 ) using data from two independent cooling periods was therefore of benefit.

Table 3. Calculated heat loss coefficients.

\begin{tabular}{lccc}
\hline & Unit 1 & Unit 2 & Unit 3 \\
\hline $\begin{array}{l}\text { Mean heat loss } \\
\text { coefficient }(\mathrm{W} / \mathrm{K})\end{array}$ & 4.5 & 4.3 & 3.9 \\
\hline
\end{tabular}

Unit 1 showed the highest heat loss rate, followed by unit 2 and unit 3. This ranking is probably a result of the unit height distribution in the stacked assembly, where unit 1 was lowest (Fig. 3). We did not observe any significant 
influence of the different PCM properties on PCM unit heat losses.

The units were installed in such a way that they could be tested individually. The large surface-to-volume ratio of an individual PCM unit resulted in unfavourably high heat loss coefficients.

\subsection{Discharge of sensible heat from liquid PCM by heat transfer to the buffer storage}

Fig. 9a shows that sensible heat was discharged for 120 minutes from fully charged PCM unit 3. At the beginning, the unit's heat exchangers were still hot $\left(\sim 75^{\circ} \mathrm{C}\right)$, which was indicated by the high initial outlet temperature (black curve). The resulting heat transfer rate (black dotted curve) therefore started at the peak value $(15 \mathrm{~kW})$. The heat transfer rate fell steadily, following the development of the decreasing HTF outlet temperature (due to falling $\mathrm{T}_{\mathrm{PCM}}$ ).

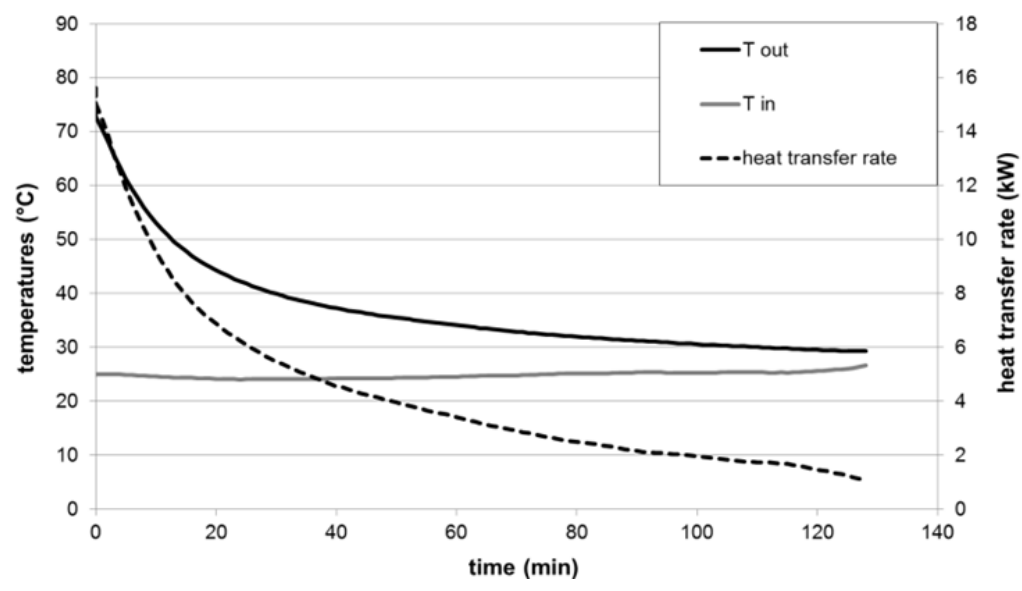

a)

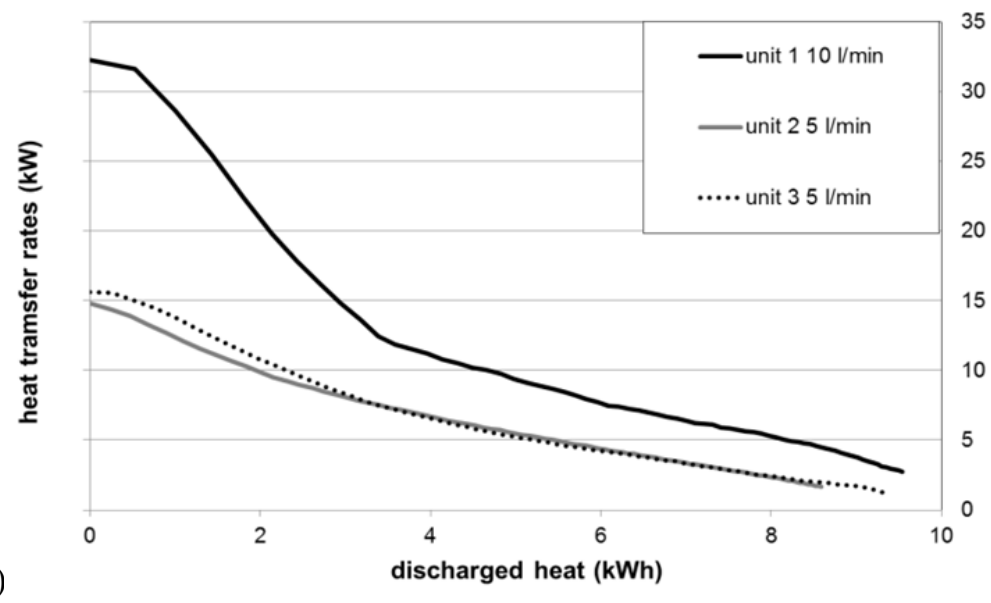

Fig. 9. a) Discharging of unit 3 with a HTF flow rate of $5 \mathrm{~L} / \mathrm{min}$; b) Comparison of heat transfer rates (active cooling).

As shown in Fig. 9b, heat transfer rates depended highly on the flow rate and the inlet temperature of the HTF. With the chosen end-criterion $\left(\mathrm{T}_{\mathrm{PCM}}=60^{\circ} \mathrm{C}\right)$ between 8.5 and $9.5 \mathrm{kWh}$ of heat were discharged from PCM units. For unit 1 (black curve), a flow rate of $10 \mathrm{~L} / \mathrm{min}$ was applied. Thermal power started at $32 \mathrm{~kW}$, when the hot HTF was pushed out of the unit's channel heat exchangers. The discharge lasted for only 70 minutes. Cooling of unit 2 (grey curve) and unit 3 (black dotted curve) with a HTF flow rate of $5 \mathrm{~L} / \mathrm{min}$ showed almost similar behaviour, but lasted for more than 130 minutes. This comparison shows that the flow regime in the heat exchangers at flow rates between 5 and $10 \mathrm{~L} / \mathrm{min}$ are similar and that heat transfer from the liquid PCM to the HTF was not a limiting factor. 


\subsection{Initialization of crystallization}

Fig. 10 shows the development of $\mathrm{T}_{\mathrm{PCM}}$ (orange curve) and the temperatures on the surface of the unit heat exchangers (sensor distribution scheme in Fig. 2a) after crystallization of the supercooled PCM unit 1 was initialized. A constant HTF flow rate of $2.13 \mathrm{~L} / \mathrm{min}$ was applied. At initial state $(\mathrm{t}=0 \mathrm{~min}), \mathrm{T}_{\mathrm{PCM}}$ was at $30{ }^{\circ} \mathrm{C}$ and the surface temperatures of the heat exchangers were lower due to HTF flow.

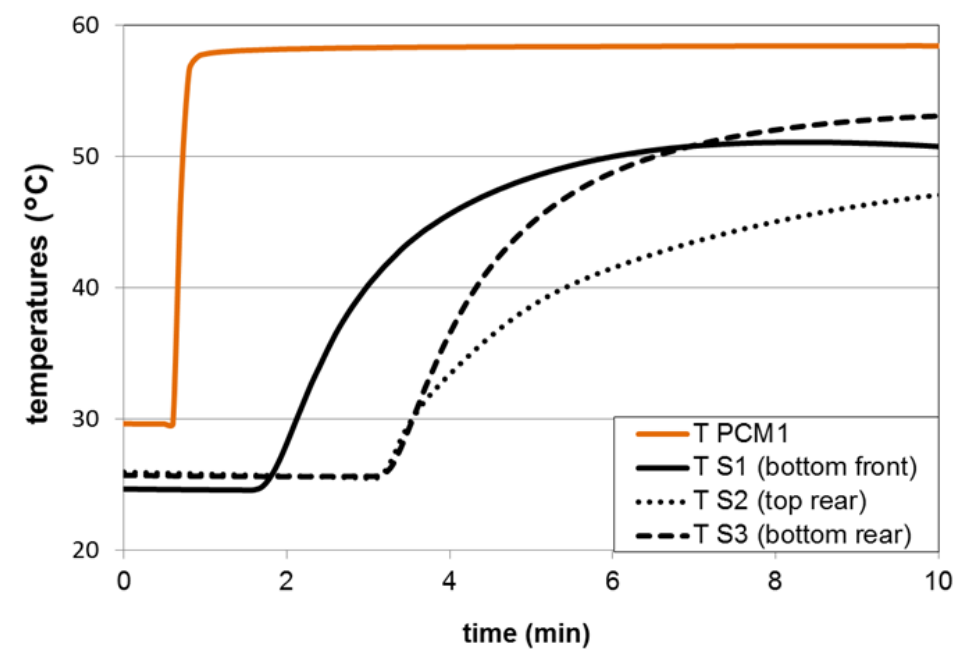

Fig. 10. Temperature developments during activation of PCM unit 1.

After a time delay of 50 seconds, $\mathrm{T}_{\mathrm{PCM}}$ started to rise sharply to $57.6^{\circ} \mathrm{C}$ and reached its maximum value of $58.4{ }^{\circ} \mathrm{C}$ after 10 more minutes. It took more than 110 seconds before the front (HTF flow direction) of the lower heat exchanger surface (indicated by $\mathrm{T}_{\mathrm{S} 1}$ ) started to heat up. $\mathrm{T}_{\mathrm{S} 1}$ reached its maximum temperature after 7 minutes and then declined slightly. $\mathrm{T}_{\mathrm{S} 2}$ and $\mathrm{T}_{\mathrm{S} 3}$, which were located about $1.6 \mathrm{~m}$ from the activation device, started to rise at $\mathrm{t}=3.5 \mathrm{~min}$. $\mathrm{T}_{\mathrm{S} 3}$ on the lower heat exchanger rose as fast as $\mathrm{T}_{\mathrm{S} 1}$, while $\mathrm{T}_{\mathrm{S} 2}$ at the rear section of the upper heat exchanger increased more slowly.

Similar surface temperature developments were observed for all PCM units. Time delays in temperature rise indicate that the crystallization expanded at a speed of about $0.7 \mathrm{~cm}$ per second, which is comparable to results for crystal growth rates in an SA-to-water $(55 \% \mathrm{wt})$ mixture from supercooled state [24]. Furthermore, surface temperature developments indicate that the heat transfer from PCM to the lower heat exchanger was better than to the upper heat exchanger. Material contraction and cavities formed on the upper side of the PCM layer could explain this, although unit 1 contained oil to fill cavities and improve the heat transfer during solidification. Solid SAT has a low thermal conductivity, which influences the unit's heat transfer capacity significantly. This should therefore be considered when an improved PCM unit is designed.

The test of the automated needle injection showed that the torque of the stepper motor was sufficient to drive the needle through the membranes into the supercooled SAT mixture and to initialize solidification, but it was too weak to push the hollow needle into a solid PCM bulk. This was indicated by the number of steps detected during the upward movement of the slider. Moreover, the hollow needle got bent and had to be replaced.

The triggering unit was designed and optimized for the 3D-printing process. During PCM charging, the whole assembly was exposed to high temperatures. After repeated heating and cooling of PCM units, the mounting profiles were deformed and showed cracks. 


\subsection{Discharge during solidification by heat transfer from PCM units to the buffer storage}

When the water tank was not cooled during discharge of PCM units (as for tapping of DHW or SH supply), HTF inlet temperatures at the PCM units increased. Fig. 11a shows this behaviour during continuous discharge of unit 2. After one hour, the inlet temperature (black curve) increased and after three hours the outlet temperature (grey curve) stagnated at a constantly low level. The heat transfer was therefore dramatically reduced. After 250 minutes, the temperature difference between inlet and outlet and the heat transfer rate were very small. The peak of thermal power $(4.1 \mathrm{~kW})$ was reached after 30 minutes, when the HTF in the unit's heat exchangers reached its maximum temperature. For the first 150 minutes, the $\mathrm{T}_{\mathrm{PCM}}$ remained at melting temperature, but then it cooled down. Discharge stopped at the chosen end-criterion $\left(\mathrm{T}_{\mathrm{PCM}}=50^{\circ} \mathrm{C}\right)$.

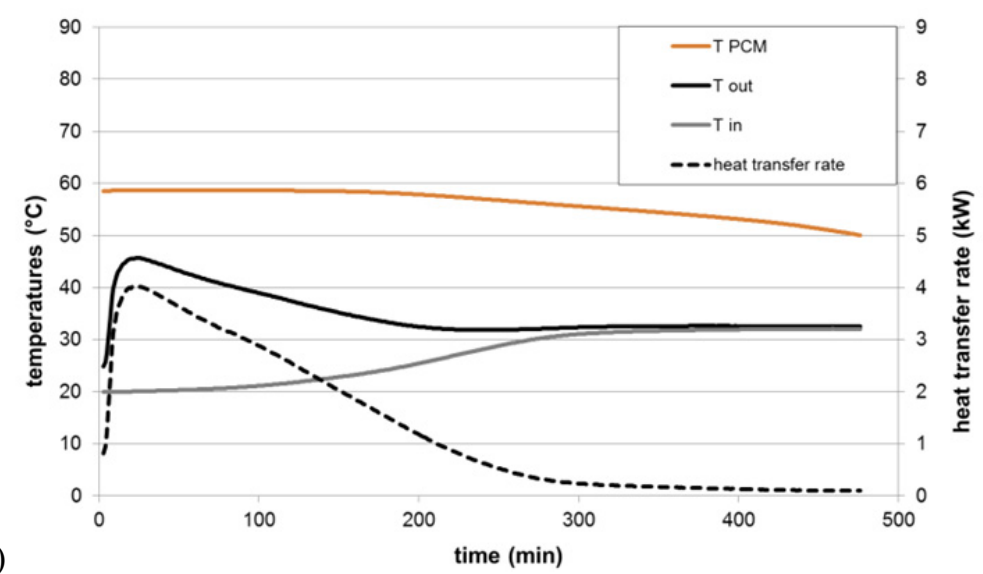

a)

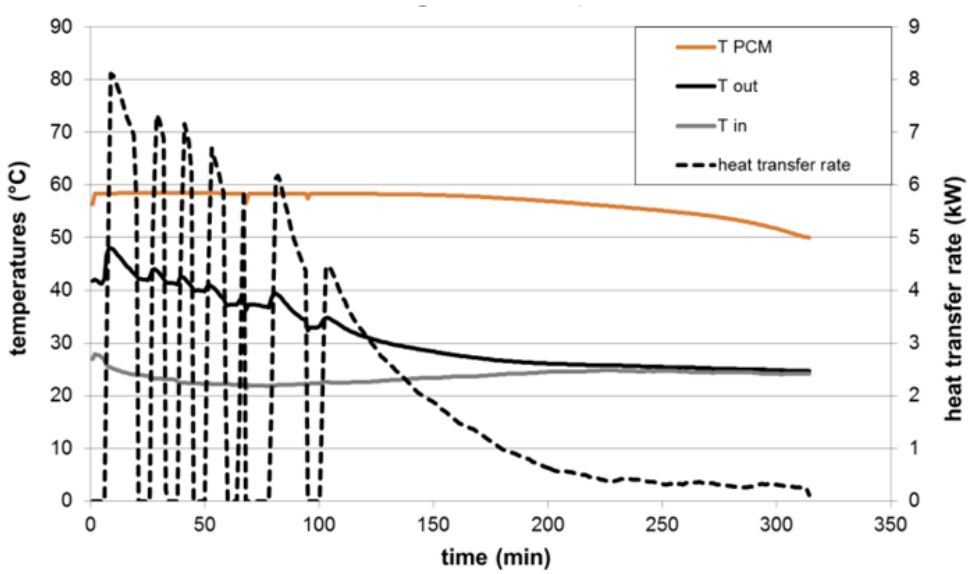

Fig. 11. Discharge after initializing solidification or supercooled PCM: a) Unit 2 with a continuous flow rate of $2.13 \mathrm{~L} / \mathrm{min}$; b) Interrupted discharge of unit 1 with a flow rate of $5 \mathrm{~L} / \mathrm{min}$.

In contrast, Fig. 11b shows values from the discharge of PCM unit 1 on a cloudy day. During periods of bright sunshine on the collector array, buffer storage charging was frequently activated by the control. The PCM unit discharge was therefore interrupted several times. In these periods, heat was transferred to the HTF in the unit's heat exchangers without flow applied. $\mathrm{T}_{\mathrm{OUT}}$ and the heat transfer rate therefore decreased more slowly during interrupted discharge. After 100 minutes, there was continuous discharge. Unit discharge stopped 5 hours after solidification was initiated. The higher flow rate applied meant that it took less time than the continuous discharge of unit 2. 
Fig. 12a shows heat transfer rate developments for discharged heat during PCM unit discharge runs. A direct comparison of PCM unit performance was possible because all the PCM box geometries were similar. Continuous discharge runs with HTF flow rates of $2.13 \mathrm{~L} / \mathrm{min}$ showed that higher heat transfer rates were achieved for units with greater heat of fusion (indicated by discharged heat).

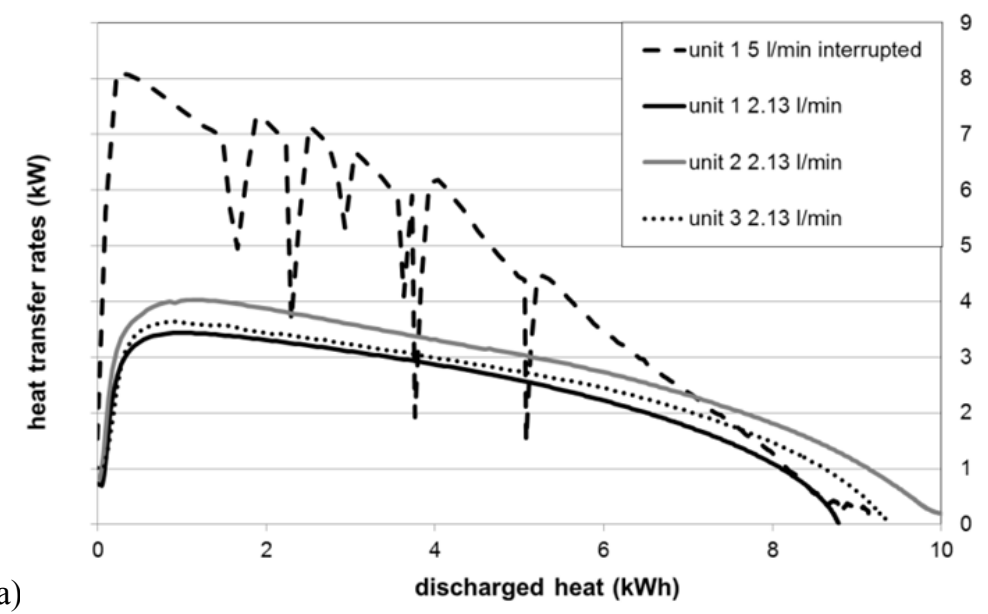

a)

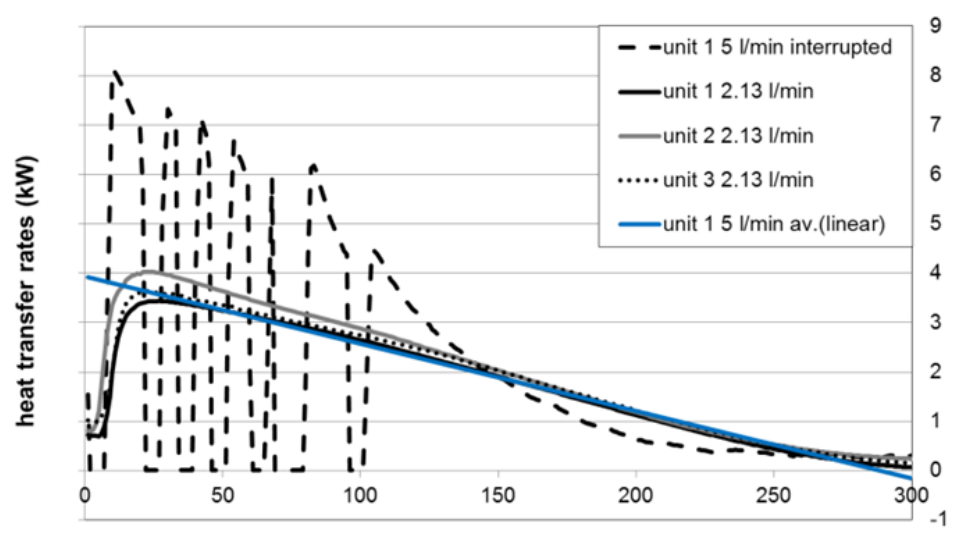

b)

time (min)

Fig. 12. Comparison of heat transfer rates during discharge with solidification from supercooled state:

a) over discharged heat; b) over time.

Unit 2, which had the highest mass of PCM (220 kg) with a high fraction of SAT in the composition, released about $10.3 \mathrm{kWh}$ of heat with a peak power over $4 \mathrm{~kW}$. Unit 1, with a PCM mass of $202 \mathrm{~kg}$ and a lower SAT fraction, had the lowest heat release $(8.8 \mathrm{kWh})$ and peak power $(3.4 \mathrm{~kW})$. Unit 3, with the same PCM mass as unit 2, released 9.4 $\mathrm{kWh}$ with slightly lower thermal power than unit 2.

In general, thermal power continuously declined during discharge after solidification of the PCM, but only dropped below $1 \mathrm{~kW}$ when more than $90 \%$ of heat had been discharged. Based on calculated $\Delta \mathrm{H}$ (Table 1 ), $78 \%$ of heat of fusion in unit $1,80 \%$ in unit 2 and $80.5 \%$ in unit 3 was utilized before the $\mathrm{T}_{\mathrm{PCM}}$ dropped to $50{ }^{\circ} \mathrm{C}$. This means that about $20 \%$ of the long-term heat storage potential of the PCM units was left.

The interrupted HTF flow in unit 1, combined with a higher volume flow rate led to substantially higher heat transfer rates when there was flow. HTF outlet temperatures were comparable to uninterrupted discharge runs. Based on the total discharge duration including periods without flow (Fig. 12b), the average heat transfer rate with interrupted 
flow almost matched the rates achieved during the continuous discharge of the same unit (HTF flow rate of $2.13 \mathrm{~L} / \mathrm{min}$ ). The interrupted flow prevented the rapid lowering of the HTF outlet temperature (Fig. 11b). During solidification, no convection took place in the PCM box. No significant influence on the heat transfer was observed at various different flow rates. This indicates low HTF flow rates in the unit's parallel heat exchangers during all runs. So we can identify conductivity as the critical parameter in the heat transfer process from PCM to HTF, which is why pulsed HTF flow was beneficial.

\subsection{Proof of concept}

Fig. 13 shows how operation modes were combined for later system demonstration to realise a sequence with combined short-term and long-term heat storage with the PCM heat storage.

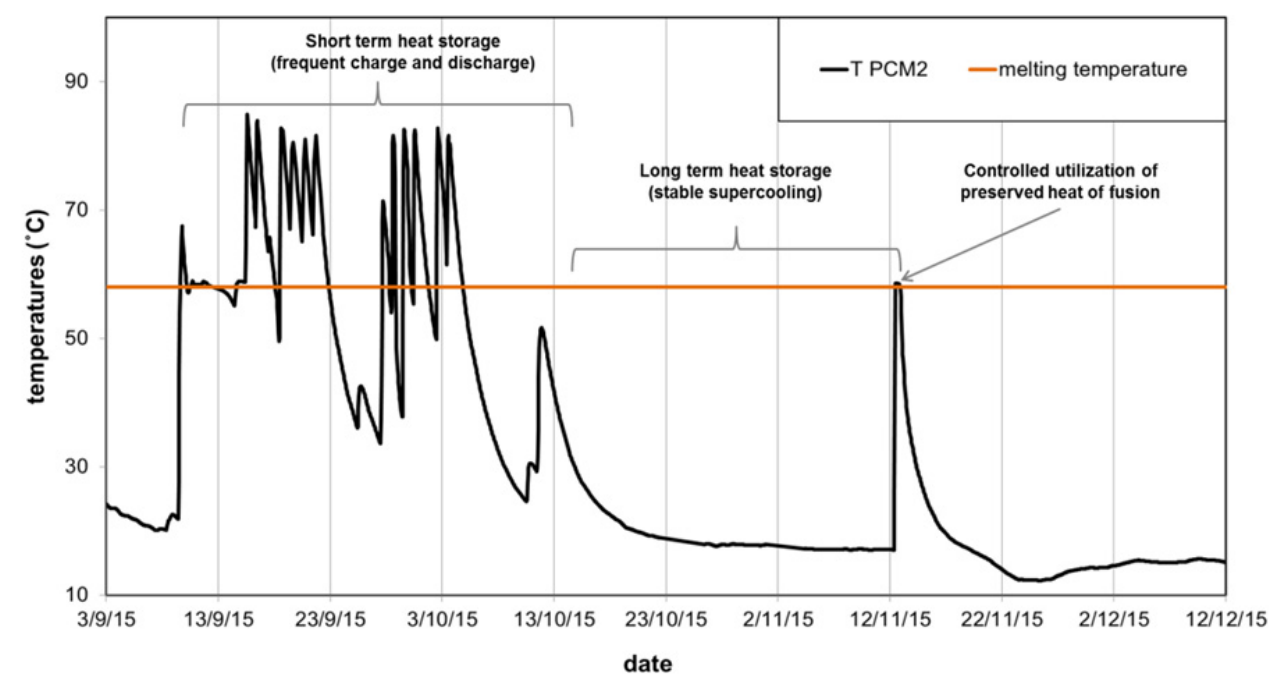

Fig. 13. Operation sequence with PCM unit charging and discharging (data from autumn 2015).

The history of PCM temperature measurements indicated the state of unit charging. In September, starting from initial solid material state, unit 2 melted. On the $9^{\text {th }}$ of September, charging stopped when $\mathrm{T}_{\mathrm{PCM} 2}$ reached $68{ }^{\circ} \mathrm{C}$. As a consequence, crystallization of the SAT composite started at its melting temperature when the unit cooled down. On the $15^{\text {th }}$ of September, full unit charging was achieved: $\mathrm{T}_{\mathrm{PCM} 2}$ exceeded $80^{\circ} \mathrm{C}$. Until the $12^{\text {th }}$ of October, sunny weather resulted in repeated charging. In periods without heat supply from the solar collector array, the unit was partly discharged to heat up the water tank and due to sensible heat losses to the ambient. After the $12^{\text {th }}$ of October, solar irradiation was insufficient to charge PCM unit 2, so it cooled to ambient temperature and remained in a stable supercooled state. The SAT composite's heat of fusion was conserved and no more heat losses occurred. The SAT composite remained in liquid state until crystallization was initiated on the $11^{\text {th }}$ of November (after 57 days) for heat transfer to the water tank. In this way, solar heat from early October was utilized for domestic heat supply in midNovember.

This demonstrates proof of concept for charging by solar thermal collectors and discharge for domestic heat supply via a water tank. The segmented heat storage can also be used for year-round system demonstration by applying a drawoff scenario for DHW and SH supply. This requires a control strategy for the initialization of PCM crystallization depending on the state of water tank charging. 


\section{Conclusions}

The heat storage concept of utilizing stable supercooling of SAT for combined long- and short-term heat storage was proved in system scale. Four PCM units, each containing 200-220 kg of sodium acetate trihydrate composites, and a $735 \mathrm{~L}$ water tank formed a segmented heat storage prototype. Hydraulic circuits and controls enabled interaction with a solar heat source and domestic hot water and space heating supply. Tests with the prototype built showed:

- For charging with solar heat, an automated sequence for the combined operation of the water tank and a variable number of PCM units enabled control of heat transfer fluid temperatures in the operation range. PCM melting with heat transfer fluid temperatures above $90{ }^{\circ} \mathrm{C}$ was possible. Fluctuating heat transfer rates from a $22.4 \mathrm{~m}^{2}$ evacuated tubular collector array peaked at $16 \mathrm{~kW}$. Fast charging (250 minutes) of an individual PCM unit was possible.

- Discharge of sensible heat from liquid and supercooled sodium acetate trihydrate composite was achieved in 3 PCM units without causing solidification. Thermal power during the discharge of a single unit reached $32 \mathrm{~kW}$ when discharged from fully heated at $80{ }^{\circ} \mathrm{C}$. Furthermore, rapid unit charging in supercooled state did not cause spontaneous crystallisation. This allowed utilization of the melted PCM as short-term sensible heat storage without compromising its long-term storage potential. Better thermal insulation and a more compact arrangement of PCM units are needed to reduce sensible heat losses.

- Initialization of crystallization with mechanical seed crystal injection worked in initial tests. However, the materials used for the activation device prototype could not withstand repeated cycles of charging and discharging. The triggering unit components must be manufactured in a more temperature-resistant material.

- During continuous discharge after solidification of the supercooled sodium acetate trihydrate composites (at heat transfer fluid flow rates of $2.13 \mathrm{~L} / \mathrm{min}$ ), heat transfer rates reached $4 \mathrm{~kW}$. The thermal power during discharge with a start and stop strategy was up to $8 \mathrm{~kW}$. This kind of "pulsed-flow" was also able to yield higher supply temperatures for domestic hot water supply and space heating via the water tank.

The functionality for typical operation modes was given. Thermal power and the flow temperatures from discharging the PCM units without and during solidification were sufficiently high to cover space heating demands in domestic buildings. However, with the present storage configuration, hot water supply must be realised with a backup heater to ensure supply temperatures above $45^{\circ} \mathrm{C}$. The heat transfer during discharge of PCM units during solidification will need to be improved to avoid this requirement.

This research proved that it is possible to store solar heat in a water tank with the combined application of shortand long-term heat storage utilizing stable supercooling of sodium acetate trihydrate. About $80 \%$ of the conserved heat of fusion was utilized during discharge from stable supercooled PCM units.

\section{Acknowledgements}

This research was funded by the European Commission (Grant Agreement N_295568) as part of the Seventh Framework Programme of the European Community for Research, Technological Development and Demonstration Activities under the funding scheme of "Collaborative Project" through the COMTES consortium. The work was also supported by the PhD program of the Sino-Danish Center for Education and Research (SDC). We thank our partners 
from Nilan A/S for sharing their knowledge and the DTU research technicians Troels V. Kristensen and Claus Aagaard for their practical assistance.

\section{References}

[1] L.F. Cabeza, L. Miró, E. Oró, A. de Gracia, V. Martin, A. Kroenauer, C. Rathgeber, M.M. Farid, H.O. Paksoy, M. Martínez, and A.I. Fernández, "CO2 mitigation accounting for Thermal Energy Storage (TES) case studies," Appl. Energy, vol. 155, pp. 365-377, 2015.

[2] Weiss W. (Editor), Solar Heating Systems for Houses, a Design Handbook for Solar Combisystems. James \& James Ltd., UK, 2003.

[3] S. Colclough and T. McGrath, "Net energy analysis of a solar combi system with Seasonal Thermal Energy Store," Appl. Energy, vol. 147, pp. 611-616, 2015.

[4] E. Andersen and S. Furbo, "Solar Combi Systems," Technical University of Denmark, Department of Civil Engineering report no. R-156, 2007.

[5] A. Thür and S. Furbo, "Compact solar Combisystem - High Efficiency by Minimizing Temperatures," Technical University of Denmark, Department of Civil Engineering report no. R-160, 2007.

[6] S. Furbo and S. Svendsen, "Report on heat storage in a solar heating system using salt hydrates," Technical University of Denmark, Thermal Insulation Laboratory, report no. 70, 1977.

[7] M. Telkes, “Thermal energy storage in salt hydrates,” Sol. Energy Mater., vol. 2, no. 4, pp. 381-393, 1980.

[8] A. Ristić, S. Furbo, C. Moser, H. Schranzhofer, A. Lazaro, M. Delgado, C. Peñalosa, L. Zalewski, G. Diarce, C. Alkan, S.N. Gunasekara, T. Haussmann, S. Gschwander, C. Rathgeber, H. Schmit, C. Barreneche, L. Cabeza, G. Ferrer, Y. Konuklu, H. Paksoy, H. Rammelberg, G. Munz, T. Herzog, J. Jänchen, and E.P. del Barrio, "IEA SHC Task 42 / ECES Annex 29 WG A1: Engineering and Processing of PCMs, TCMs and Sorption Materials," Energy Procedia, vol. 91, no. June, pp. 207-217, 2016.

[9] B. Mette, H. Kerskes, H. Drück, and H. Müller-Steinhagen, "New highly efficient regeneration process for thermochemical energy storage,” Appl. Energy, vol. 109, pp. 352-359, 2013.

[10] B. Zettl, G. Englmair, and G. Steinmaurer, "Development of a revolving drum reactor for open-sorption heat storage processes," Appl. Therm. Eng., vol. 70, no. 1, pp. 42-49, 2014.

[11] B. Zettl, G. Englmair, and W. Somitsch, “An Open Sorption Heat Storage Concept and Materials for Building Heat Supply,” Energy Procedia, vol. 73, pp. 297-304, 2015.

[12] R. Weber and V. Dorer, "Long-term heat storage with NaOH,” Vacuum, vol. 82, no. 7, pp. 708-716, 2008.

[13] B. Fumey, R. Weber, and L. Baldini, "Liquid sorption heat storage - A proof of concept based on lab measurements with a novel spiral fined heat and mass exchanger design," Appl. Energy, vol. 200, pp. 215-225, 2017.

[14] X. Daguenet-Frick, P. Gantenbein, J. Müller, B. Fumey, and R. Weber, "Seasonal thermochemical energy storage: Comparison of the experimental results with the modelling of the falling film tube bundle heat and mass exchanger unit," Renew. Energy, vol. 110, pp. 162-173, 2016.

[15] H. Zondag, B. Kikkert, S. Smeding, R. De Boer, and M. Bakker, "Prototype thermochemical heat storage with open reactor system,” Appl. Energy, vol. 109, pp. 360-365, 2013.

[16] P.A.J. Donkers, L.C. Sögütoglu, H.P. Huinink, H.R. Fischer, and O.C.G. Adan, “A review of salt hydrates for seasonal heat storage in domestic applications," Appl. Energy, vol. 199, pp. 45-68, 2017.

[17] J. Pereira da Cunha and P. Eames, "Thermal energy storage for low and medium temperature applications using phase change materials - A review," Appl. Energy, vol. 177, pp. 227-238, 2016.

[18] J.A. Quinnell and J.H. Davidson, "Heat and mass transfer during heating of a hybrid absorption/sensible storage tank," Sol. Energy, vol. 104, pp. 19-28, 2014. 
[19] J.M. Schultz and S. Furbo, "Investigation of heat of fusion storage for solar low energy buildings," Proc. Sol. World Congr. 2005 Bringing Water To World, vol. 3, pp. 1833-1838, 2005.

[20] S. Puupponen, V. Mikkola, T. Ala-Nissila, and A. Seppälä, "Novel microstructured polyol-polystyrene composites for seasonal heat storage," Appl. Energy, vol. 172, no. April, pp. 96-106, 2016.

[21] B. Zalba, J.M. Marín, L.F. Cabeza, and H. Mehling, "Review on thermal energy storage with phase change: materials, heat transfer analysis and applications," Appl. Therm. Eng., vol. 23, no. 3, pp. 251-283, 2003.

[22] N. Araki, M. Futamura, A. Makino, and H. Shibata, "Measurements of Thermophysical Properties of Sodium Acetate Hydrate," International J. Thermophys., vol. 16, no. 6, pp. 1455-1466, 1995.

[23] B. Sandnes and J. Rekstad, "Supercooling salt hydrates: Stored enthalpy as a function of temperature," Sol. Energy, vol. 80, no. 5, pp. 616-625, May 2006.

[24] T. Ohachi, M. Hamanaka, H. Konda, and S. Hayashi, I. Taniguchi, T. Hashimoto, and Y. Kotani "Electrical nucleation and growth of $\mathrm{NaCH}_{3} \mathrm{COO} 3 \mathrm{H}_{2} \mathrm{O}$," J. Crystal Growth, vol. 99, nos. 1-4, pp. 72-76, 1990.

[25] D. Zhou, C.Y.Zhao, and Y. Tian, "Review on thermal energy storage with phase change materials (PCMs) in building applications," Appl. Energy, vol. 92, pp. 593-605, 2012.

[26] A. Sharma, V.V Tyagi, C.R. Chen, and D. Buddhi, "Review on thermal energy storage with phase change materials and applications," Renew. Sustain. Energy Rev., vol. 13, no. 2, pp. 318-345, Feb. 2009.

[27] W. Cui, Y. Yuan, L. Sun, X. Cao, and X. Yang, "Experimental studies on the supercooling and melting/freezing characteristics of nano-copper/sodium acetate trihydrate composite phase change materials," Renew. Energy, vol. 99, pp. 1029-1037, 2016.

[28] J. Guion and M. Teisseire, "Nucleation of sodium acetate trihydrate in thermal heat storage cycles," Sol. Energy, vol. 46, no. 2, pp. 97-100, 1991.

[29] A. López-navarro, J. Biosca-Taronger, J.M. Corberán, C. Peñalosa, A. Lázaro, P. Dolado, and J. Payá, "Performance characterization of a PCM storage tank," Appl. Energy, vol. 119, pp. 151-162, 2014.

[30] C. Zauner, F. Hengstberger, B. Mörzinger, R. Hofmann, and H. Walter, "Experimental characterization and simulation of a hybrid sensible-latent heat storage," Appl. Energy, vol. 189, pp. 506-519, 2017.

[31] A. Frazzica, M. Manzan, A. Sapienza, A. Freni, G. Toniato, and G. Restuccia, "Experimental testing of a hybrid sensible-latent heat storage system for domestic hot water applications," Appl. Energy, vol. 183, pp. 1157-1167, 2016.

[32] P. Moreno, L. Miró, A. Solé, C. Barreneche, C. Solé, I. Martorell, and L.F. Cabeza, "Corrosion of metal and metal alloy containers in contact with phase change materials (PCM) for potential heating and cooling applications," Appl. Energy, vol. 125, pp. 238-245, 2014.

[33] A. Arteconi, N.J. Hewitt, and F. Polonara, "State of the art of thermal storage for demand-side management," Appl. Energy, vol. 93, pp. 371-389, 2012.

[34] S. Furbo, "Investigations of Heat Storages with salt hydrate as storage medium based on the extra water principle," Technical University of Denmark, Thermal Insulation Laboratory report no. 80, 1978.

[35] M. Dannemand, J. Dragsted, J. Fan, J.B. Johansen, W. Kong, and S. Furbo, "Experimental investigations on prototype heat storage units utilizing stable supercooling of sodium acetate trihydrate mixtures," Appl. Energy, vol. 169, pp. 72-80, 2016.

[36] M. Dannemand, J.M. Schultz, J.B. Johansen, and S. Furbo, "Long term thermal energy storage with stable supercooled sodium acetate trihydrate," Appl. Therm. Eng., vol. 91, pp. 671-678, 2015.

[37] M. Dannemand, J.B. Johansen, and S. Furbo, "Solidification behavior and thermal conductivity of bulk sodium acetate trihydrate composites with thickening agents and graphite," Sol. Energy Mater. Sol. Cells, vol. 145, pp. 287-295, 2016. 
[38] M. Dannemand, J. Fan, S. Furbo, and J. Reddi, "Validation of a CFD Model Simulating Charge and Discharge of a Small Heat Storage Test Module based on a Sodium Acetate Water Mixture," Energy Procedia, vol. 57, pp. 2451-2460, 2014.

[39] W. Kong, M. Dannemand, J.B. Johansen, J. Fan, J. Dragsted, G. Englmair, and S. Furbo, "Experimental investigations on heat content of supercooled sodium acetate trihydrate by a simple heat loss method," Sol. Energy, vol. 139, pp. 249-257, 2016.

[40] G. Zhou and Y. Xiang, "Experimental investigations on stable supercooling performance of sodium acetate trihydrate PCM for thermal storage,” Sol. Energy, vol. 155, pp. 1261-1272, 2017.

[41] M.A. Rogerson and S.S.S. Cardoso, "Solidification in heat packs: III. Metallic trigger," AIChE J., vol. 49, no. 2, pp. 522-529, 2003.

[42] S. Furbo, J. Fan, E. Andersen, Z. Chen, and B. Perers, "Development of seasonal heat storage based on stable supercooling of a sodium acetate water mixture," Energy Procedia, vol. 30, pp. 260-269, 2012.

[43] J. Fan, S. Furbo, E. Andersen, Z. Chen, B. Perers, and M. Dannemand, "Thermal behavior of a heat exchanger module for seasonal heat storage,” Energy Procedia, vol. 30, pp. 244-254, 2012.

[44] M. Dannemand, J.B. Johansen, W. Kong, and S. Furbo, "Experimental investigations on cylindrical latent heat storage units with sodium acetate trihydrate composites utilizing supercooling," Appl. Energy, vol. 177, pp. 591-601, 2016.

[45] J.M. Schultz and S. Furbo, "Solar heating systems with heat of fusion storage with 100\% solar fraction for solar low energy builidngs," in ISES Solar World Congress 2007 Proceedings, 2007, pp. 2721-2725.

[46] K. Seo, S. Suzuki, T. Kinoshita, and I. Hirasawa, "Effect of Ultrasonic Irradiation on the Crystallization of Sodium Acetate Trihydrate Utilized as Heat Storage Material," Chem. Eng. Technol., vol. 35, no. 6, pp. 10131016, 2012.

[47] M.A. Rogerson and S.S.S. Cardoso, "Solidification in heat packs: II. Role of cavitation," AIChE J., vol. 49, no. 2, pp. 516-521, 2003.

[48] M.A. Rogerson and S.S.S. Cardoso, "Solidification in heat packs: I. Nucleation rate," AIChE J., vol. 49, no. 2, pp. 505-515, 2003.

[49] L. Wei and K. Ohsasa, "Supercooling and Solidification Behavior of Phase Change," ISIJ Int., vol. 50, no. 9, pp. 1265-1269, 2010.

[50] P.L. Dietz, J.S. Brukner, and C.A. Hollingsworth, "Linear Crystallization Velocities of Sodium Acetate in Supersaturated Solutions,” J. Phys. Chem., vol. 61, no. 7, pp. 944-948, 1957.

[51] L.F. Cabeza, A. Castell, C. Barreneche, A. de Gracia, and A.I. Fernández, "Materials used as PCM in thermal energy storage in buildings: A review,” Renew. Sustain. Energy Rev., vol. 15, no. 3, pp. 1675-1695, 2011.

[52] G.A. Lane, Solar heat storage latent heat material, Volume 1: Background and Scientific Principles. CRC, 1983.

[53] K.N. Marsh (Editor), Recommended Reference Materials for the Realization of Physicochemical Properties. Oxford: Blackwell Scientific Publications, 1987.

[54] J.V. Sengers and J.T.R. Watson, "Improved International Formulations for the Viscosity and Thermal Conductivity of Water Substance," Journal of Physical and Chemical Reference Data, vol. 15, no. 4. pp. 1291$1314,1986$.

[55] J. Dragsted, S. Furbo, M. Dannemand, and F. Bava, "Thermal stratification built up in hot water tank with different inlet stratifiers," Sol. Energy, vol. 147, pp. 414-425, 2017.

[56] S. Furbo and V. Korsgaard, "Varmelagring til solvarmenanlæg," Technical University of Denmark, Thermal Insulation Laboratory report no. 162, 1984. 